\title{
Changes in the network of tourist trails in the border zones of the Czech Republic after entering the Schengen area
}

\author{
Krzysztof KoŁODZIEJCZYK (iD https://orcid.org/oooo-0002-3262-311X; - e-mail: krzysztof.kolodziejczyk@uwr.edu.pl \\ Department of Regional Geography and Tourism, Institute of Geography and Regional Development, University of Wroclaw, \\ Wroclaw 50-137, Poland
}

Citation: Kołodziejczyk K (2020) Changes in the network of tourist trails in the border zones of the Czech Republic after entering the Schengen area. Journal of Mountain Science 17(4). https://doi.org/10.1007/s11629-019-5809-9

(C) The Author(s) 2020

\begin{abstract}
Among the factors influencing tourist trail network development are political issues, including the presence of state borders, the possibility of crossing them and the accessibility of border zones. In the article, it was decided to look at changes in the offer of tourist trails (hiking and cycling) along the entire border of the Czech Republic after the extension of the Schengen area (within this area, crossing the border is possible anywhere, and not only at official border crossings). It should be emphasized here that the borders of the Czech Republic over most of their length run through mountainous areas and, apart from political factors, natural features should have a major impact on the development of tourist routes. In order to determine the coherence of the current network of trails on both sides of the Czech Republic state border, modern tourist maps have been analyzed, determining the number of places where it is possible to cross the state border with the help of a marked tourist trail. Based on that, two indicators were introduced to determine the degree of openness with all neighboring countries as regards the opportunity to cross on a tourist trail. Changes in the historical situation, a comparison of the accessibility of the border area before entering the Schengen area and 2019, were analyzed for two study areas using archival maps. Over a decade after the extension of the Schengen area, the number of places where tourist trails of neighboring countries approach the border has clearly increased. Crossing is more often made possible using hiking trails than cycling routes (trails of the first type cross the border every $7.91 \mathrm{~km}$, while the latter every $13.3 \mathrm{~km}$ ), but
\end{abstract}

Received: 21-Sep-2019

Revised: 18-Feb-2020

Accepted: 04-Mar-2020 considering the speed of movement, it can be assessed that the openness for cyclists is higher than for hikers. Moreover, in many places there is still significant potential for further integration of tourist trail networks as trails created in one country often do not have a continuation on the other side of the border.

Keywords: Tourist trails; Schengen area; Border zone; Mountains; Czech Republic

\section{Introduction}

The development of a network of tourist trails is dependent on many factors of both a natural and human nature (Kowalczyk and Derek 2010). Among the latter, political factors seem to have a huge impact on the shape of networks (Potocki 2004, 2010, 2013), especially in the border zones of selected countries (Anderson and O'Dowd 1999), and in particular those characterized by low international openness. In the case of Central and Eastern Europe, the political factor played a crucial role during the communist period. Although states such as Czechoslovakia, the German Democratic Republic and Poland were part of the so-called Soviet bloc, being under the control of the Union of Soviet Socialist Republics, crossing their state borders or even staying in their neighborhood was very difficult and often required special permits or passes (Sroka 2013). However, the borders of these countries with the states of the western (democratic) bloc were even more strictly 
controlled. Sometimes even a ten or more kilometer-wide border zone was deprived of residents, inaccessible to anyone except for the army and closely guarded so that no one could illegally enter the West (the situation refers e.g . to the Czechoslovak-German and Czechoslovak-Austrian borders). As a result, tourist trails appeared rarely in the border zone, and only near borders with other countries of the Soviet bloc. The situation changed after the collapse of the communist system in Central and Eastern Europe (Illner 1996; Roszkowski 2003). Although the borders still constituted a barrier to communication, the border zone became in practice freely accessible and tourist trails could be marked as everywhere else. As a result, in the 1990s the networks of tourist trails,

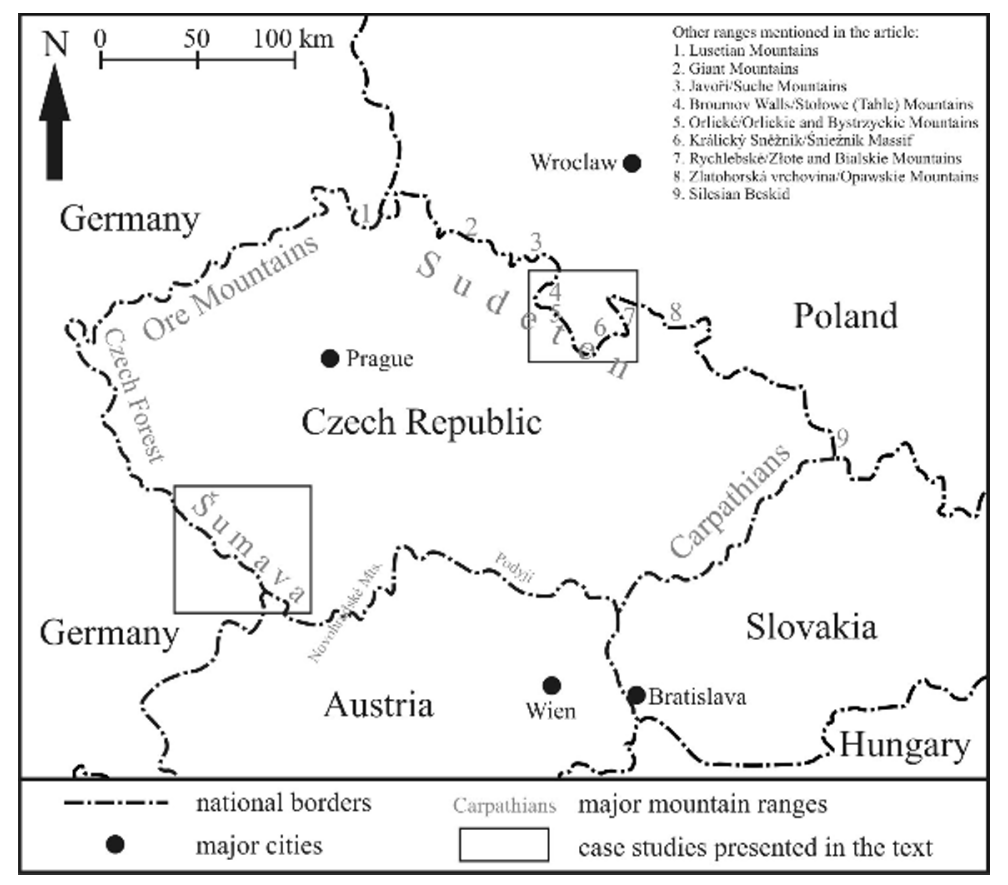

Figure 1 Major mountain ranges surrounding the Czech Republic. initially mostly footpaths, but later also cycling, were significantly expanded. However, the networks on both sides of the state border were still not consistent, mostly because it could be crossed in selected places only (however, the number of such places increased, as new crossings were introduced - this was connected with socalled small border traffici ${ }^{1)}$, as well as that of a tourist character). It was only at the end of 2007 when Central European countries entered the Schengen area that it gave the opportunity to fully link the networks of tourist trails on both sides (Kolejka et al. 2015). The changes that followed are analyzed in the article.

The Czech Republic is distinguished by its specific relief. The interior of the country is made up of mainly lowland areas with large plains but also hilly landscapes, while mountain ranges surround the whole country (Figure 1): Carpathians in the east, Sudeten mountains (Czech Krkonošsko-jesenická subprovincie or Sudety) in the north, Ore Mountains (Czech Krušné hory) in the north-west, Czech Forest (Czech Český les) in the west, Šumava (Bavarian Forest) in the southwest and the Novohradské Mountains in the south (Pánek et al. 2016). In principle, only parts of the north-eastern and southern sections of the state border lack typical mountainous landscapes, but in

the second case among the upland areas still there are regions with a mountainous character (e.g. the Podyji National Park, where the Dyje River has carved a deep valley with steep slopes). The state border of the Czech Republic usually runs along the highest ridges of the mountain ranges, mostly along the main watersheds (compare: Kolejka et al. 2015). Taking into account that mountains constitute an important area for tourism development, a large part of the attractive and popular tourist areas in the Czech Republic is located in border areas (Faracik 2008). Such regions include the Giant Mountains (Czech Krkonoše), Broumov Walls (Czech Broumovské stěny), Orlické Mountains and the Sněžník Massif in the Sudeten, Czech 'Switzerland' (Czech České Švýcarsko), selected parts of the Ore Mountains and Šumava. During the communist period, when the Czech Republic was part of Czechoslovakia, the areas close to the borders with the Federal Republic of Germany and Austria remained inaccessible (at certain distances from the border there were a series of barbed wire fences and 'noman's land', Figure 2). The smaller number of mountain tourist regions in the interior of the country forced the authorities to make mountain ranges in the north of the country accessible near

\footnotetext{
${ }^{1)}$ Small border traffic referred to border crossings, in which case crossing was only possible for residents of border communes.
} 
the borders with states belonging to the same political bloc: Poland and the German Democratic Republic. The result was relatively good accessibility of the border zone in the north of Czechoslovakia, much better than in neighboring Poland (Mazurski 2012; Staffa 1981, 1986; Tyszkiewicz 2006) where for many years no tourist trails were created in the zone between the last public road and the state border (Dudziak and Potocki 1995).

In 1989 Czechoslovakia changed its political system from socialist to capitalist (Illner 1996; Klaus 2006), and on January 1, 1993 it split into the Czech Republic and Slovakia, the border running along the highest parts of the Western Carpathians. The period of political transformation was connected with a significant reconstruction and development of the network of tourist trails. The process mainly covered previously inaccessible parts of the country near the borders with the Federal Republic of Germany and Austria (Vystoupil and Sauer 2012). Many valuable natural areas were then made available for tourism for the first time since the inter-war period (before 1938) (e.g. the current Podyjí National Park; Kołodziejczyk 2015a). Although numerous tourist border crossings began to emerge quite quickly, the state border remained a barrier. The Czech Republic joined the Schengen area on December 21, 2007 together with Estonia, Lithuania, Latvia, Poland, Slovakia, Slovenia, Hungary and Malta. The Schengen Agreement dates from 1985 when controls at the internal borders of the signatory states were abolished. Crossing may take place in principle anywhere, unless regulations say otherwise (e.g. in national parks). All the countries

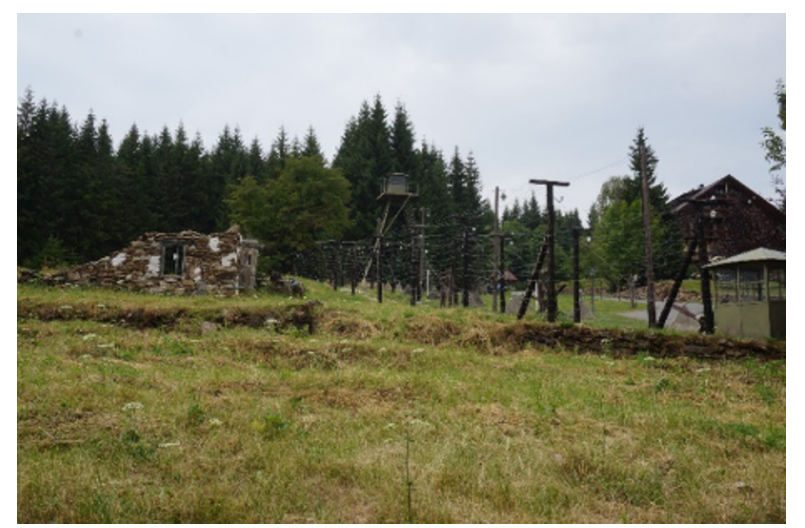

surrounding the Czech Republic also belong to the Schengen area, so all controls have disappeared and all areas on both sides have become fully available to citizens of the neighboring countries. This was another impulse for the development of the network of tourist trails which from that time began more and more often to lead to the state border and facilitate its crossing. Their network developed mainly in mountain areas, especially in their higher parts. These changes have also made the political factor less and less important in the development of the network in the Czech Republic, and the key role, as before 1938 in Czechoslovakia, is played by natural factors such as the possibility of routing a trail across diverse terrain, along a river network, the need to protect selected natural habitats, as well as the location of attractive places. Popularity of certain types of active tourism is also important and it has to be highlighted that mountain biking has developed very much in Central Europe in the last decade, e.g. complex networks of MTB trails were created in Nové Město pod Smrkem and Świeradów-Zdrój (transboundary, Czech-Polish center, however most trails are located in the first country; Kołodziejczyk 2014b, 2015a), in mountain ranges located north-east from the Kłodzko basin (Bardzkie and Złote Mountains) in Poland, and in the northeastern part of Rychlebské Mountains in the Czech Republic.

The aim of the article is to track changes in the network of tourist trails caused by the entry of the Czech Republic into the Schengen area. The analysis covers hiking and cycling routes leading to or running along its state borders with all its neighbors (Figure 1). The effect will be an assessment of the degree of cohesion of the current

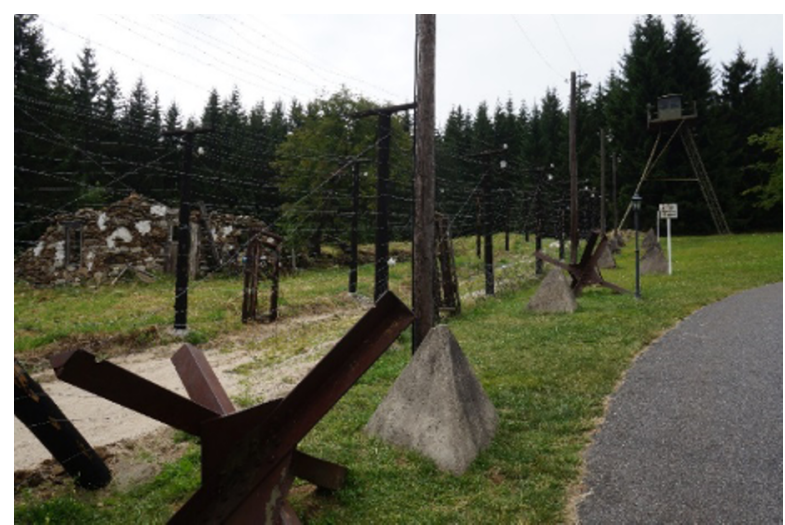

Figure 2 Reconstruction of the fortifications, which during the communist period lined the borders of Czechoslovakia with Austria and the Federal Republic of Germany: an example from Bučina in Šumava (photos: author 2019). 
network and the tourist openness of these borders (using two indicators). Of course, nowadays, borders can be crossed anywhere, however, in mountainous areas, and such features accompany most of the state borders of the Czech Republic, relief and vegetation (as well as for protective reasons) make tourists choose marked tourist routes as a means for crossing the areas, as they indicate the right of way and provide relative safety. Therefore, an important issue seems to be an analysis of the effects of the entry of the Czech Republic to the Schengen area in the prospect of the development of a tourist trail offer. The specific objectives of this article are:

- To determine the coherence of the network of tourist trails on both sides of the state borders of the Czech Republic and its neighbors since the expansion of the Schengen area more than 10 years ago. A decade seems to be the right time to assess the effects of this event in the history of the region and its impact on tourism. In the same way the openness of state borders was assessed, regarding the opportunity to cross them using tourist trails.

- To track historical changes, that is comparing the availability of the border zone before entering the Schengen zone and in 2019. These analyses will be carried out for selected regions on the basis of case studies.

- To emphasize the restoration of relations between natural and human factors affecting the development of the network of trails. After more than four decades whose dominant role was the political factor, natural factors again have a decisive role.

Research on the development of trail networks over the years has been primarily based on the analysis of archival maps and the archives of associations that deal with route planning and mapping. Studies are better developed in the mountain ranges with a long tradition of active tourism, primarily hiking, and an extensive network of trails. An example is the Sudeten mountains, where research was conducted primarily by Chmiel (2011), Potocki (2004, 2010, 2013) and Kołodziejczyk (2014a, 2015a, 2015b, 2018, 2019a, 2019b), the latter focusing on recent years and changes after the entry of Poland and the Czech Republic into the Schengen area. Krakowiak (1997) and Styperek (2001, 2002) also conducted analyses of the degree of development of the networks, focusing on the Polish Carpathians. On the other hand, the wider effects of extending the Schengen area to include Central and Eastern European countries have been studied among others by Dołzbłasz (2012, 2017a, 2017b) or Dołzbłasz and Raczyk (2015, 2016). The borderlands of the Czech Republic were additionally studied from other social and economic perspectives (e.g. Dokoupil et al. 2011; Górecka and Tomczak 2008; Vaishar et al. 2013), as well as ecological (Więckowski 2013).

\section{Tourist Trails and Internal Accessibility of a Region}

The most important function of tourist trails is communication as they enable tourists to move between selected points in a safe and interesting way (Lijewski et al. 2002; Kowalczyk and Derek 2010; Stasiak, Śledzińska and Włodarczyk 2014). Therefore, they are part of the transport accessibility of a reception area (Stasiak 2006). When discussing this accessibility for a selected tourist region (Celata 2007), account is taken of external access, i.e. a tourist's access from his permanent place of residence, and internal access, i.e. the ability to move within a selected region and take trips from the place of temporary accommodation to selected tourist attractions (Kowalczyk and Derek 2010). Tourist trails can be an element of both external and internal accessibility, although they seem to be more important in the second case. External accessibility may be determined by long-distance tourist routes, primarily dedicated to car tourism, but also to cycling, hiking, horse riding or kayaking. In this case, a tourist already on the way from permanent residence to reception area implements an assumed 'tourist program' associated with visiting places, and sometimes traveling in a different way (e.g. by bicycle with panniers). However, this is relatively rare. Tourist routes are definitely more often used as an element of internal accessibility, i.e. in order to penetrate an area to be visited (implementation of tourist goals) and engage in various forms of active tourism or recreation. They complement the network of public roads, public transport, cable cars and lifts, providing access to a number of attractive places, primarily on a micro 
scale. For example, a given mountain massif can be reached by car or public transport, but tourist trails lead to individual attractions (peaks or viewpoints). They can often be the only way to reach a particular place, e.g. in difficult terrain (rocks, wetlands) or for legal reasons in protected areas (Stasiak and Styperek et al. 2014). Internal accessibility is determined by both local and regional trails, as well as long-distance routes which form part of a larger network and sections in connection with other routes can constitute one-day trips.

\section{Materials and Methods}

The basic method used in the article is an analysis of selected tourist maps. In order to determine the coherence of the current network of tourist trails on both sides of the Czech Republic's state borders, modern tourist maps have been analyzed, determining the number of places where it is possible to cross with the help of marked trails. However, only hiking and cycling routes were considered being the most common in the Czech Republic (Vystoupil and Sauer 2012). This types of trails occur in all mountain ranges surrounding the country, while other (e.g. skiing) are far less popular and available only in certain regions, depending on natural conditions (e.g. snow cover). Educational paths were counted as hiking trails as this corresponds to the form of movement (besides, educational paths usually coincide with regular hiking trails). Places where trails from both sides converge were counted, additionally taking into account those where it was marked from one side, but only if there is a public road or a path on the other to potentially continue the trip. However, pressure was placed on the first element because the issue concerns the coherence of the network. Knowing the number of places where it is possible to cross by the means of tourist trails, they were assigned to individual sections of the state border, corresponding to each neighboring country. By comparing the number of places where crossing is possible with the length of a given section, information was obtained on the degree of coherence of the tourist trail network with Czech Republic's individual neighbors. The analysis was conducted for the first half of 2019. Furthermore, for selected sections of border a comparison of the situation before and after the extension of the Schengen area was presented. The measure used is largely simplified and does not take into account local conditions, e.g. when the border runs along a river or inaccessible wetlands are located along it. However, given the considerable length of individual sections of the borders, such local conditions should not affect significantly the final result. Moreover, as emphasized above, the border has, for most of its length, a similar character along main mountain ranges. As a result, areas with noteworthy height differences or wetlands, where the possibility of marking a tourist trail is significantly limited, appear more or less randomly on its various sections. In comparison with other borders (e.g. Polish-German), the sections along rivers are relatively short, moreover these are often small watercourses (mountain streams) over which it is possible to build a simple footbridge.

Changes in historical terms, i.e. a comparison of the accessibility of the border zone before entering the Schengen area and now, were traced in details for two areas (Figure 1): 1) Šumava (Bavarian Forest) within the borders of the Czech national park (which is accompanied by a smaller national park and a protected landscape area on the German side of the border), and 2) the mountain ranges surrounding the Kłodzko basin (Czech-Polish border). The choice of the first research area resulted from the fact that within national parks, tourists' mobility is limited to some extent. In both parks (on both sides of the border) in the first (core) zone, movement is permited on marked tourist trails only. As a result, in many places, formal trails are the only way to cross the state border. The author wanted to check whether the Czech Republic's entry into the Schengen area resulted not only in an increase in the number of routes crossing the state border, but also, at the same time, the borders of the national parks. Attention was additionally paid to whether the possible improvement of the internal accessibility of the national parks complied with the principles of protection of such areas (Ceballos-Lascuráin, ed. 1996; Dudek 2017; Ptaszycka-Jackowska and Baranowska-Janota 1989). In turn, the selection of the Kłodzko basin as a research area resulted from the specific course of the border, surrounded by the Czech Republic on three sides, and the border runs through the highest points of the surrounding 
Table 1 Maps included in the analysis

\begin{tabular}{|c|c|c|}
\hline Study area & $\begin{array}{l}\text { The period before the Czech } \\
\text { Republic joins the Schengen area }\end{array}$ & Contemporary situation \\
\hline $\begin{array}{l}\text { Sumava and Bayerischer } \\
\text { Wald national parks }\end{array}$ & SHOCart 2002 & $\begin{array}{l}\text { https://mapy.cz/ (Internet map, regularly } \\
\text { updated); Geodézie On Line }(2014,2018)\end{array}$ \\
\hline $\begin{array}{l}\text { Mountain ranges } \\
\text { surrounding Kłodzko } \\
\text { basin }\end{array}$ & $\begin{array}{l}\text { ExpressMap 2007; Plan 2007; } \\
\text { SHOCart } 2008\end{array}$ & $\begin{array}{l}\text { https://mapy.cz/, https://mapa-turystyczna.pl/ } \\
\text { (Internet maps, regularly updated) }\end{array}$ \\
\hline
\end{tabular}

mountains, which themselves are what makes the region so attractive. In this case, on the Polish side there is a national park (Stolowe/Table Mountains; Kasprzak et al. 2012; Rogowski 2017), hence on a certain part of the border the possibility of crossing exists only when using tourist trails (the proportion of this section in the entire analyzed border is, however, small). Both areas chosen as case studies represent landscapes of medium-scale mountains reaching a maximum height of about $1,400 \mathrm{~m}$.

The changes were traced on the basis of former (from before the Czech Republic's entry to the Schengen area) and contemporary tourist maps (Table 1). All places where hiking and cycling trails reached the state border were taken into account, while the focus was on those places where the trails of both countries met. The maps produced indicate additionally the places where the trails lead to the border from one side only, but only on the condition that there is a path or road on the other side to continue hiking or cycling, and the area is not included in a core protection zone. Although these places allow crossing they do not constitute an integration of trail networks, hence they were omitted in the next stage of the analysis which consisted in the drawing of concentric circles at 2.5 and $5 \mathrm{~km}$ from places where the border can be crossed using a tourist trail. The assumed distance corresponds approximately to between one and two hours of hiking. It is true that a hiker is able to cover a distance of up to $4 \mathrm{~km}$ in one hour, but taking into account the terrain and the generally winding course of most tourist trails, this distance expressed as a straight line is much smaller. As a result, the area from which a hiker can reach the state border in a relatively short time, then cross it and still make a trip into the neighboring country (and then return to the place of accommodation) is depicted. For cyclists who travel much faster, the accessibility of crossing points is much better.

The field studies were carried out in Šumava in
2005 and 2019, and annually in the Kłodzko basin to 2019 and how tourist flows operate near the borders was observed. The marking in the area of crossing points and the tourist infrastructure related to them (information boards and information points, resting places) were also taken into account.

\section{Results - the Tourist Openness of Czech Republic Borders}

To determine the degree of openness of the borders of the Czech Republic with all neighboring countries as regards the possibility of crossing the border on tourist routes, two indicators were calculated. The first one defines the frequency of places where crossing the border using a tourist trail is possible, i.e. it is determined by calculating the frequency of crossing points $(\mathrm{km}$ per one crossing point). This indicator has therefore a deterrent character ${ }^{2}$, because from a tourist's perspective they should be as frequent as possible, hence the distance between them should be as small as possible. The degree of openness of the border is then higher. In this case, however, only such places were considered where a full integration of tourist trails from both neighboring countries is found i.e. where trails leading from both countries meet. In many cases, the route leading to the border from one country has no continuation on the other side. These trails improve the accessibility of the border area in general, but do not necessarily allow an inexperienced tourist to cross the border. It is then necessary to have an accurate map that will show unmarked paths and the continuation of the journey. Hence, it was decided to introduce a second indicator which determines how many such instances are found. This indicator has therefore also a deterrent character, because the fewer such

${ }^{2)}$ In this case an increase in the value of the explanatory variable leads to a decrease in the value of the explained variable. 
Table 2 Number of places where crossing the Czech Republic state border is possible using tourist trails

\begin{tabular}{|c|c|c|c|c|c|c|c|}
\hline \multirow[b]{2}{*}{$\begin{array}{l}\text { Section of the } \\
\text { border }\end{array}$} & \multirow[b]{2}{*}{ Characteristic } & \multicolumn{3}{|c|}{ Crossings on hiking trails } & \multicolumn{3}{|c|}{ Crossings on cycling trails } \\
\hline & & $\begin{array}{l}\text { both } \\
\text { sides }{ }^{\dagger}\end{array}$ & $\begin{array}{l}\text { Czech } \\
\text { side } \neq\end{array}$ & $\begin{array}{l}\text { neighboring } \\
\text { country side }^{\S}\end{array}$ & $\begin{array}{l}\text { both } \\
\text { sides }{ }^{\dagger}\end{array}$ & $\begin{array}{l}\text { Czech } \\
\text { side } \neq\end{array}$ & $\begin{array}{l}\text { neighboring } \\
\text { country side }^{\S}\end{array}$ \\
\hline \multirow{3}{*}{$\begin{array}{l}\text { with Germany } \\
(818.949 \mathrm{~km})\end{array}$} & number* & 105 & 35 & 47 & 61 & 27 & 17 \\
\hline & percent (\%) & 56.15 & 18.72 & 25.13 & 58.10 & $25 \cdot 71$ & 16.19 \\
\hline & $\begin{array}{l}\text { av. distance }{ }^{* *} \\
(\mathrm{~km})\end{array}$ & 7.80 & - & - & 13.43 & - & - \\
\hline \multirow{3}{*}{$\begin{array}{l}\text { with Poland } \\
\text { (795.782 km) }\end{array}$} & number* & 117 & 13 & 29 & 58 & 36 & 10 \\
\hline & percent (\%) & $73 \cdot 58$ & 8.18 & 18.24 & $55 \cdot 77$ & 34.62 & 9.61 \\
\hline & $\begin{array}{l}\text { av. distance }{ }^{* *} \\
(\mathrm{~km})\end{array}$ & 6.80 & - & - & 13.72 & - & - \\
\hline \multirow{3}{*}{$\begin{array}{l}\text { with Slovakia } \\
(251.762 \mathrm{~km})\end{array}$} & number* & 51 & 26 & 5 & 19 & 5 & 7 \\
\hline & percent (\%) & 62.19 & 31.71 & 6.10 & 61.29 & 16.13 & 22.58 \\
\hline & $\begin{array}{l}\text { av. distance }{ }^{* *} \\
(\mathrm{~km})\end{array}$ & 4.94 & - & - & 13.25 & - & - \\
\hline \multirow{3}{*}{$\begin{array}{l}\text { with Austria } \\
(460.379 \mathrm{~km})\end{array}$} & number* & 21 & 11 & 17 & 37 & 2 & 11 \\
\hline & percent (\%) & 42.86 & 22.45 & 34.69 & 74.00 & 4.00 & 22.00 \\
\hline & $\begin{array}{l}\text { av. distance }{ }^{* *} \\
(\mathrm{~km})\end{array}$ & 21.92 & - & - & 12.44 & - & - \\
\hline \multirow{5}{*}{$\begin{array}{l}\text { Total } \\
(2,326.872 \mathrm{~km})\end{array}$} & number* & 294 & 85 & 98 & 175 & 70 & 45 \\
\hline & percent (\%) & 61.63 & 17.82 & 20.55 & 60.34 & 24.14 & $15 \cdot 52$ \\
\hline & $\begin{array}{l}\text { av. distance }{ }^{* *} \\
(\mathrm{~km})\end{array}$ & $7 \cdot 91$ & - & - & 13.30 & - & - \\
\hline & number* & \multicolumn{3}{|l|}{477} & \multicolumn{3}{|l|}{290} \\
\hline & $\begin{array}{l}\text { total } \\
\text { number*** }\end{array}$ & \multicolumn{3}{|l|}{767} & & & \\
\hline
\end{tabular}

Note: *means the number of crossings; **means the average distance between crossings which was counted only for the situation when trails from both sides of the border meet because only it corresponds to the full integration of tourist trails of neighboring countries; ${ }^{* * *}$ means the total number of crossings.

tmeans trails from both sides of the border; $¥$ means trails from the Czech side only; §means trails from the side of the neighboring country only.

places, the greater the coherence of the network of routes on both sides. When calculating the second indicator, only such locations were taken into account when on the other side there is an unmarked track that allows further movement. Therefore, situations where relief, vegetation cover or legal factors prevent entering the territory of a neighboring country were ignored. The situation when a trail has no counterpart in the neighboring country can result from underdevelopment of route network, but also from lower tourism needs on one side of the border. Sometimes there are no interesting places to lead new trails. So it has to be remembered that existence of a trail on one site of the border not necessary is a reason for founding new trail on the other side. For the need of this analysis this factor was simplified and the attractiveness of the area and tourists' needs were not taken into account.

As for the first indicator, for the total length of the state borders of the Czech Republic, hiking trails allow crossing on average every $7.91 \mathrm{~km}$, while for cycling routes the result is $13.3 \mathrm{~km}$ (Table
2). Considering the speed of a hiker, depending on the terrain, this distance corresponds to about 2 hours of walking, while for cyclists it is about 1 hour. It can therefore be concluded that cycling routes provide better opportunities to cross the border (although the frequency of crossing places is lower). The results, however, are quite diverse for individual sections of the border, corresponding to individual neighbors of the Czech Republic, especially when it comes to hiking trails (Table 2).

The highest frequency of hiking trails is across the Czech-Slovak border at every $4.94 \mathrm{~km}$ (Table 2). This is due to the numerous ties between these countries, which in 1918-1938 and 1945-1992 constituted one state: Czechoslovakia. After its disintegration into the Czech Republic and Slovakia, there were therefore quite a lot of road border crossings between them, which were later supplemented with tourist crossings and those having special regulations (so-called small border traffic). Therefore, after the accession of both countries to the Schengen area, the development of the network was relatively small as it was already 
quite sufficient. In addition, the Czech-Slovak border runs along the Western Beskids range, a popular tourist destination which enabled the development of a network of marked routes pre2007. The coherence of the network of hiking trails along the Czech-Polish and Czech-German borders is quite similar (crossing points on tourist trails every 6.8 and $7.8 \mathrm{~km}$, respectively). Both sections of the border were more difficult to access during the communist period, especially the border with the Federal Republic of Germany. The slightly better coherence of the hiking trail network on the Czech-Polish border in comparison with the CzechGerman section is due to the attractiveness of the areas where the state border runs. In the Sudeten mountains, it usually leads along the major, highest and most attractive ridges, while in the Ore Mountains it is much more often on hillsides or along valleys which are less scenic. Hence, even during the communist period, the density of hiking trails on the Czechoslovak side of the Sudeten mountains was quite high (also considering restrictions on movement in the border area, as mentioned above). In addition, since the 1970s, the first routes appeared in both countries leading close to the border or even along it, although of course without the chance to cross to a neighboring country except for a few road border crossings. After the political changes in the early 1990s, such well-developed networks were much easier to connect and develop. In the Ore Mountains the development of the network of hiking trails progressed more slowly, not to mention Šumava (Breuer et al. 2010) where in the border zone it was possible only after the fall of communism when this area became once again fully available. The entry of the Czech Republic and Poland into the Schengen area resulted in a significant integration of all networks by creating new access routes. In the case of the Czech-Polish border, the process was particularly intense in the Central Sudeten mountains (Kołodziejczyk 2019b), because in the western section the integration had already taken place, in the Krkonoše/Karkonosze Mountains ${ }^{3}$ ) (Giant Mountains) it was even during the communist period 4 ), while in the eastern section the state border runs at the northern foot of the mountains through less attractive areas, hence there was less demand (although few new hiking trails leading to the border were established in the Zlatohorská vrchovina/Opawskie Mountains and their surroundings; see Bukała 2011; Chmiel 2011). The Czech-Austrian border is characterized by the lowest frequency of places for crossing on hiking routes. The figure of $21.92 \mathrm{~km}$ is almost three times higher than in the case of the Czech-German border and almost 4.5 times higher than in the case of the Czech-Slovak border. This is due to several factors: 1) a generally lower density of the hiking trail network in some parts of the southern Czech Republic and northern Austria (being probably the most important reason), 2) less attractive terrain (smaller share of mountainous, picturesque areas, especially comparing to not so distant mountain ranges and national parks), 3) the lack of accessibility from the Czechoslovakian side during the communist period, 4) a relatively large share of sections along rivers.

As for cycling trails, the value of the first indicator is around $13 \mathrm{~km}$, which means that taking into account the course of the border, the cycling routes of both countries allow to cross it every 13 $\mathrm{km}$ (Table 2). The highest indicator, suggesting the least integration, is found on the Czech-Polish border. This is related to the nature of relief in the border area, which, located along the highest parts of the mountains, is quite diverse and does not always allow cycling trails to be marked. In addition, two national parks are located at the border where opportunities to cycle are significantly reduced. The lowest figure, in turn, concerns the Czech-Austrian border, where the less diverse terrain allows almost unlimited planning of a cycling trail network (with only minor exceptions, mostly connected with rivers). It should be emphasized that in the Czech Republic and in all neighboring countries the beginnings of bicycle trail development is in the 1990 s, i.e. the period when the accessibility of the border area was already quite good. The development of cycling

3) First the Czech, and then the Polish name is presented.

4) Integration of tourist trails in the Giant Mountains dates back to $19^{\text {th }}$ century or even earlier (Dudziak and Potocki 1995; Lindrová 2018; Lokvenc 2006; Mazurski 2012; Potocki 2004). It is a result of a very early $\left(18^{\text {th }}-19^{\text {th }}\right.$ century) development of tourism on both sides of the mountains (can be even called mass tourism), partly connected with balneology (few spas located in the region, e.g. Bad Warmbrunn in Prussia at that time, now Cieplice Śląskie-Zdrój in Poland, or Janské Lázně in the Czech Republic). Although the changing political conditions influenced later tourism development, this historical factor has affected the current situation significantly. 
routes in border zones from the beginning was connected with crossings of various character: road, tourist and part of the so-called small border traffic (with special regulations), and after the Czech Republic, Poland and Slovakia joined the Schengen area, associated generally with all existing roads.

The second indicator tells us how many of the total number of places where trails allow tourists to reach or cross the border is served by a trail leading from one country only (Table 2). In other words, a situation where a trail has no equivalent on the other side of a border, although the possibility exists. In this situation, there is no integration of the trail networks. However, these data provide information on the potential for further development and integration as they indicate the best place to mark new trails. As for hiking, the lack of continuation of a trail on the other side of a border is most often connected with the CzechAustrian border $(57.14 \%$ of all the routes reaching the border), and least often with the Czech-Polish border (26.42\%). The problem of the lack of integration in both cases concerns to a greater extent the Czech side, because more often neighboring routes have no continuation on the territory of the Czech Republic than vice versa. On the Czech-Polish border, the places where the routes reach it from the Czech side only are more than twice less than locations to which only Polish routes lead. In the case of the Czech-Austrian border, the proportion is around 1.5. A similar situation applies to the Czech-German border where out of 187 places where hiking trails reach the border, in as many as $43.85 \%$ they do not have a continuation, but again German trails do so more often. On the Czech-Slovak border it is the opposite. In this case $37.81 \%$ of the trails reaching the border have no continuation, but it concerns existing Czech trails about five times more often. This is due to the more intensive development of the Czech network relative to Slovakian in the period after the political transformation in the 1990s. On the entire length of the state border of the Czech Republic out of 477 places where hiking trails were established, in as many as 183 cases (38.37\%) the routes do not have continuation on the other side, with 85 Czech trails (17.82\%, no continuation in the neighboring country) and 98 from neighboring countries (20.55\%, no equivalent on the Czech side). Thus, it can be seen that the Czech network of hiking trails, despite the fact that it is already very well developed, could be further expanded in the border area in order to achieve greater integration with the networks of neighboring countries (Germany, Poland and Austria). Only in the case of the Czech-Slovak border does more work need to be done by Czech Republic's neighbor.

In the case of cycling trails, for the entire length of the Czech Republic borders there are 290 places where marked trails reach the border, in 115 cases $(39.66 \%)$ they do not have continuation on the other side, and this is more common for Czech trails (24.14\%) than for those leading from another country (15.52\%; Table 2). Thus, it can be seen that the Czech cycling trail organizers sought to develop the network in the border zone more than in the case of neighboring countries (and also better than Czech hiking trails). The highest percentage without continuation on the other side occur on the Czech-Polish border (44.53\% of the total), and the lowest on the Czech-Austrian (26\%). This corresponds very well with the results of the first indicator on the frequency of crossing places using tourist trails. Although for hiking trails the border with Austria had the worst result, and that with Poland the second best, for cycling trails the CzechAustrian border was the best and for the CzechPolish the worst. The second indicator confirmed these relations, hence it can be concluded that in the case of the Czech-Austrian border the network of hiking trails is poorly integrated, but of cycling trails really well, and in the case of the CzechPolish border the reverse. The second indicator for the borders with Germany and Slovakia had quite similar results, in about $40 \%$ of cases when cycling trails reach the state border they do not have their equivalent in the neighboring country, although in the case of the Czech-German border the problem lies mainly on the German side, and in the case of the Czech-Slovak border on the Czech side.

A comparison of the situation before and after the Czech Republic (and all its neighboring countries) entered the Schengen area was carried out for the Czech-Polish border (and also in more detail for two research areas - see case studies below). The choice of only one border results from the availability of maps, which must show the network of routes at a good scale and at the right time. They are not available for all sections of the border. Comparing the situation in 2007 and 2019 
Table 3 Number of places where crossing the Czech-Polish state border was possible using tourist trails before the extension of the Schengen area (2007) and nowadays (2019)

\begin{tabular}{l|l|l|l|l|l|l} 
& \multicolumn{3}{c}{ Crossings on hiking trails } & \multicolumn{3}{c}{ Crossings on cycling trails } \\
Year & $\begin{array}{l}\text { trails from both } \\
\text { sides of the } \\
\text { border }\end{array}$ & $\begin{array}{l}\text { trails from the } \\
\text { Czech side } \\
\text { only }\end{array}$ & $\begin{array}{l}\text { trails from the } \\
\text { Polish side } \\
\text { only }\end{array}$ & $\begin{array}{l}\text { trails from both } \\
\text { sides of the } \\
\text { border }\end{array}$ & $\begin{array}{l}\text { trails from } \\
\text { the Czech } \\
\text { side only }\end{array}$ & $\begin{array}{l}\text { trails from the } \\
\text { Polish side } \\
\text { only }\end{array}$ \\
\hline 2007 & 42 & 9 & 6 & 44 & 14 & 7 \\
2019 & 117 & 13 & 29 & 58 & 36 & 10 \\
Change (2019/2007) & 2.79 & 1.44 & 4.83 & 1.32 & 2.57 & 1.43
\end{tabular}

Notes: The results for 2007 should be treated as estimates because the author used maps showing the situation in different years (2004-2007), supporting himself with his own notes and photos. The complete map set for the entire border could not be obtained for 2007 .

Table 4 Number of places where crossing the Czech-Polish state border was possible using tourist trails before the extension of the Schengen area (2007) and nowadays (2019) in selected mountain ranges

\begin{tabular}{|c|c|c|c|c|c|c|c|c|c|c|c|c|}
\hline \multirow{3}{*}{ Region } & \multicolumn{6}{|c|}{ Crossings on hiking trails } & \multicolumn{6}{|c|}{ Crossings on cycling trails } \\
\hline & \multicolumn{2}{|c|}{$\begin{array}{l}\text { trails from } \\
\text { both sides of } \\
\text { the border }\end{array}$} & \multicolumn{2}{|c|}{$\begin{array}{l}\text { trails from } \\
\text { the Czech } \\
\text { side only }\end{array}$} & \multicolumn{2}{|c|}{$\begin{array}{l}\text { trails from } \\
\text { the Polish } \\
\text { side only }\end{array}$} & \multicolumn{2}{|c|}{$\begin{array}{l}\text { trails from } \\
\text { both sides of } \\
\text { the border }\end{array}$} & \multicolumn{2}{|c|}{$\begin{array}{l}\text { trails from } \\
\text { the Czech } \\
\text { side only }\end{array}$} & \multicolumn{2}{|c|}{$\begin{array}{l}\text { trails from } \\
\text { the Polish } \\
\text { side only }\end{array}$} \\
\hline & 2007 & 2019 & 2007 & 2019 & 2007 & 2019 & 2007 & 2019 & 2007 & 2019 & 2007 & 2019 \\
\hline $\begin{array}{l}\text { Giant Mountains } \\
\text { (Krkonoše/Karkonosze } \\
\text { Mountains) }\end{array}$ & 8 & 31 & $\mathrm{O}$ & 0 & 0 & o & 2 & 2 & o & 8 & 1 & o \\
\hline $\begin{array}{l}\text { Javoří/Suche } \\
\text { Mountains }\end{array}$ & 2 & 14 & $\mathrm{O}$ & 0 & 0 & 3 & 1 & 4 & $\mathrm{O}$ & o & 1 & 2 \\
\hline $\begin{array}{l}\text { Broumov } \\
\text { Walls/Stołowe (Table) } \\
\text { Mountains }\end{array}$ & 2 & 8 & $\mathrm{O}$ & 0 & 0 & 1 & 3 & 3 & 1 & 2 & $\mathrm{O}$ & o \\
\hline $\begin{array}{l}\text { Orlické/Orlickie and } \\
\text { Bystrzyckie Mountains }\end{array}$ & 5 & 10 & 1 & 1 & $\mathrm{O}$ & 1 & 3 & 3 & 3 & 3 & $\mathrm{O}$ & $\mathrm{o}$ \\
\hline $\begin{array}{l}\text { Králický Sněžník/ } \\
\text { Śnieżnik Massif }\end{array}$ & 3 & 7 & $\mathrm{O}$ & 0 & 0 & 1 & 2 & 2 & $\mathrm{O}$ & 1 & $\mathrm{O}$ & $\mathbf{O}$ \\
\hline $\begin{array}{l}\text { Rychlebské/Złote and } \\
\text { Bialskie Mountains }\end{array}$ & 5 & 14 & $\mathrm{O}$ & 3 & $\mathrm{O}$ & 5 & 2 & 2 & 2 & 6 & O & O \\
\hline Silesian Beskid & 5 & 12 & 1 & 7 & o & 6 & 1 & 5 & 1 & 4 & o & O \\
\hline
\end{tabular}

on the Czech-Polish border, a significant increase in the number of places where it can be crossed using tourist trails is noticeable (Table 3). The greater change concerns hiking trails, which results from the much greater accessibility of mountain areas after the extension of the Schengen area, where new routes could be marked on the basis of a dense network of old roads and paths, sometimes even forgotten after World War II or previously used only by experienced tourists who know the area really well. Cycling trails are more common in areas with smaller height differences and use local asphalt and forest or field roads. Before 2007, in places where they crossed the border, there were often formal border crossings, and therefore also bicycle routes, hence the clearly smaller increase. In the case of places where the marked routes of both countries meet, for hiking trails there was almost a three-fold increase, while for cycling trails - 14 new places occurred between 2007 and 2019
(Table 3). Although it is not really desirable, the increase also included places where trails were marked from only one country. Based on this data, it can be concluded that between 2007 and 2019 in the border area Czech managers were generally more active in the field of cycling trails, and Polish - hiking.

Looking at the data for selected mountain ranges of the Czech-Polish border (Table 4), there is a clear improvement in the possibility of crossing the border based on hiking trails, especially in the Giant Mountains, Javoří/Suche Mountains, Broumov Walls/Stołowe (Table) Mountains (despite the existence of the Polish national park), and the Rychlebské/Złote and Bialskie Mountains. In the last case, as well as in the Silesian Beskid, there are several places where a hiking trail does not have its equivalent on the other side of the border, which is an undesirable situation and indicates a poor network integration and 
insufficient correlation of activities of route managers on both sides of the border. As for bicycle routes, the changes are smaller, and in some ranges almost imperceptible (Broumov Walls/Stołowe (Table) Mountains, Orlické/Orlickie and Bystrzyckie Mountains, Králický Sněžník/ Śnieżnik Massif), which is associated with the lack of technical possibilities to create new trails (no suitable roads, too high slopes) or nature protection needs. Slightly larger changes took place in the Javoří/Suche Mountains and Silesian Beskid, although in the latter there is a problem with integration again (similarly in the Giant Mountains, but there it results from the principles of making both national parks accessible to tourists, especially on the Polish side).

\section{Case study - Šumava and Bayerischer Wald National Parks}

The Šumava National Park is located in southwest Czech Republic. Established in 1991, it covers an area of $680.6 \mathrm{~km}^{2}$ and stretches from northwest to southeast, being adjacent to Germany over most of its area (Dickie et al. 2014) where the Bayerischer Wald (Bavarian Forest) National Park is located $\left(242 \mathrm{~km}^{2}\right)$. Only in the southeastern part does the Sumava National Park stretch along the Czech-Austrian border. The Šumava together with the neighboring Bavarian Forest creates the most extensive forest complex in Central Europe, sometimes referred to as the "Green Roof of Europe" (Křenová and Kiener 2012). The landscape of Šumava varies between the northwestern and southeastern parts. Within the first area there are vast plateaus with emergent peaks and deep valleys formed by fluvial erosion, while in the second the most important features are the impressive Trojmezná mountain massif and the Vltava alluvial plain. Both parts are home to various valuable communities of plant and animal species among which some postglacial species exist within numerous peatland communities and are especially important. Within the national park the remains of primeval mountain forests, glacial lakes, mountain and valley raised bogs can be found, as well as relics of farming that used to be much more intensive than today (Breuer et al. 2010; Těšitel at al. 2003a). The whole territory is important in a world context and Šumava is a UNESCO biosphere reserve while the local peat bogs are protected by the Ramsar Convention for the Protection of Wetlands (Kušová and Těšitel 2016; Křenová and Kiener 2012; Těšitel and Kušová 2010). At the same time the area is a very popular tourist destination (approximately 2 million every year), however it is mostly domestic (Dickie et al. 2014; Gorner and Čihař 2013; see also: Picek et al. 2007; Těšitel et al. 2003b).

In 2002, Czech tourist trails through the Šmava National Park reached the state border in nine places and various types of border crossings were organized, but only in four of them were there marked trails on the other side: in two cases German and in two Austrian (Figure 3). The Czech trails reached the border mainly in the southeastern part of the region, where they were connected with two regular road border crossings (Czech-German Strážný - Philippsreut and CzechAustrian Zadní Zvonková - Schöneben) and five tourist crossings (Czech-German České Žleby Bischofreut; Stožec - Haidmühle; Nové Údolí, Třístoličník - Dreisessel; and Czech-Austrian Plešné jezero - Holzschlag I/3-10, Figure 4a; Nová Pec - Holzschlag). Of these crossings, only in the second, fifth and sixth cases were tourist routes also marked on the other side. The better opportunity to cross the border on a tourist trail were in the southeastern part of the national park and resulted from its better accessibility in connection with a large number of tourist attractions. The mountain range on both sides of the border is narrower here and the width of the Czech national park is smaller than in its northwestern part. A railway line runs along the range and almost reaches the state border near the village of Stožec and the settlement of Nové Údolí. Among the attractions are Plechý $(1378 \mathrm{~m})$, the highest Czech peak of Šumava, post-glacial Plešné lake, open rock faces and the viewpoint at the border summit Tř́stoličník/Dreisessel, Trojmezí the meeting point of the Czech Republic, Germany and Austria (Figure 4b), and an $18^{\text {th }}$-century channel for floating timber, a unique technical monument that stretches along a significant part of the mountain range. The channel crosses the modern state border twice and in both places tourist border crossings were functioning in 2002, but one was located outside the national park. In 


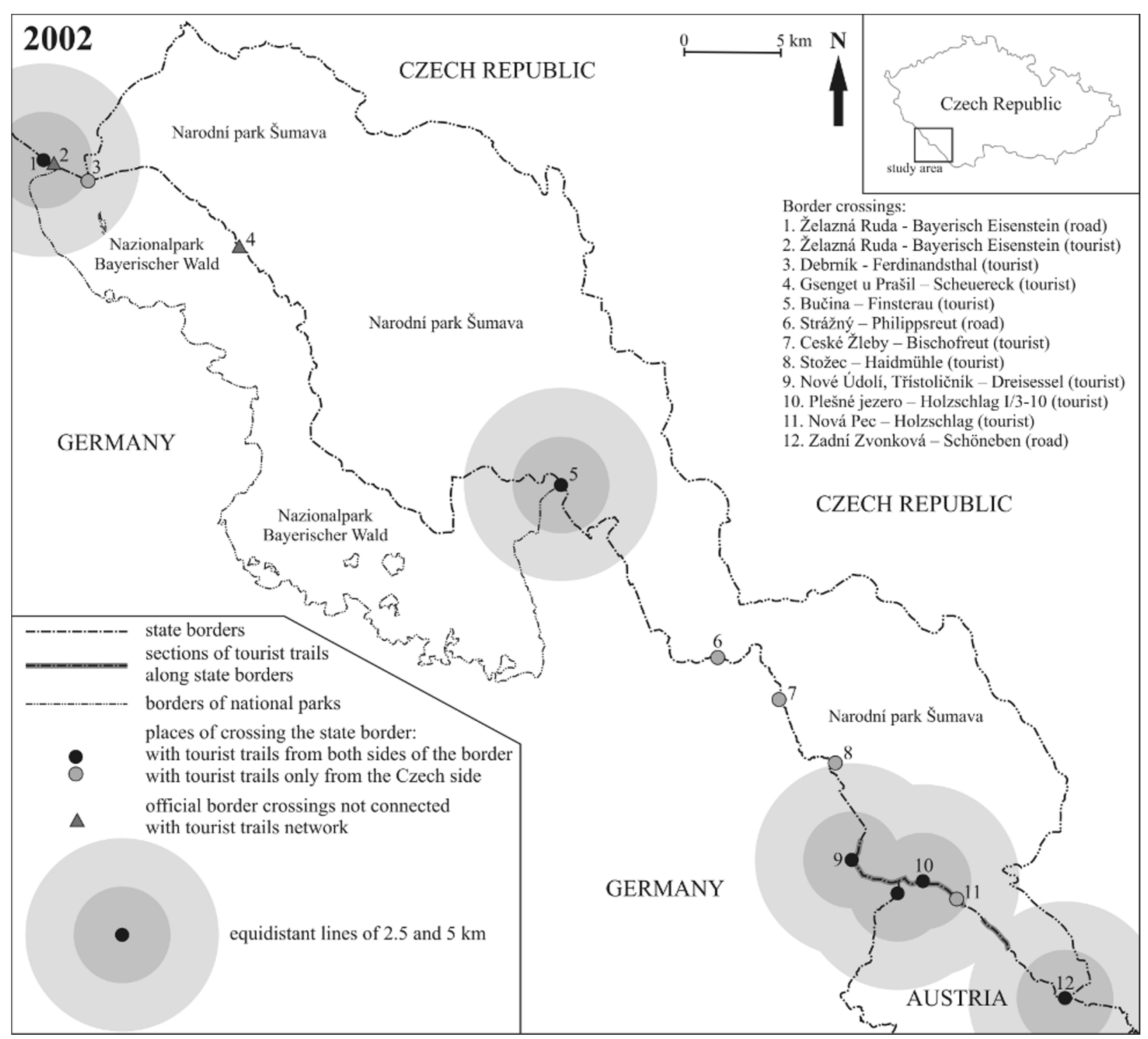

Figure 3 Crossing places on the Czech Republic border using tourist trails in Šumava and Bayerischer Wald National Parks in 2002.

addition, in the vicinity of the park there is a reservoir on the Vltava, a popular holiday destination with campsites and beaches. All these factors meant that tourist pressure on the park area was high, which resulted in the creation of more tourist border crossings and trails connecting them with the tourist settlements.

In 2002, there was only one tourist border crossing in the central part of the national park at Bučina - Finsterau (the German national park extends west of here; Figure 3). Tourist routes led to it from both sides of the border. Unlike the border crossings listed above, where there was at most a small parking lot (depending on car access) and a resting place, in the Czech Bučina there was a tourist information point (nowadays open only occasionally). In 2002, two more border crossings were located in the northern part of the park, however one of them (Gsenget $u$ Prašil Scheuereck) was not directly connected to the tourist trail network (the nearest trail was $0.7 \mathrm{~km}$ on the Czech side and $1.3 \mathrm{~km}$ on the German side), and a marked trail reached the second crossing only from the Czech side. The next two border crossings (road and tourist) were northwest of the Czech national park, respectively 3 and $2.5 \mathrm{~km}$ from its borders between the towns of Želazná Ruda and Bayerisch Eisenstein. The noticeably 

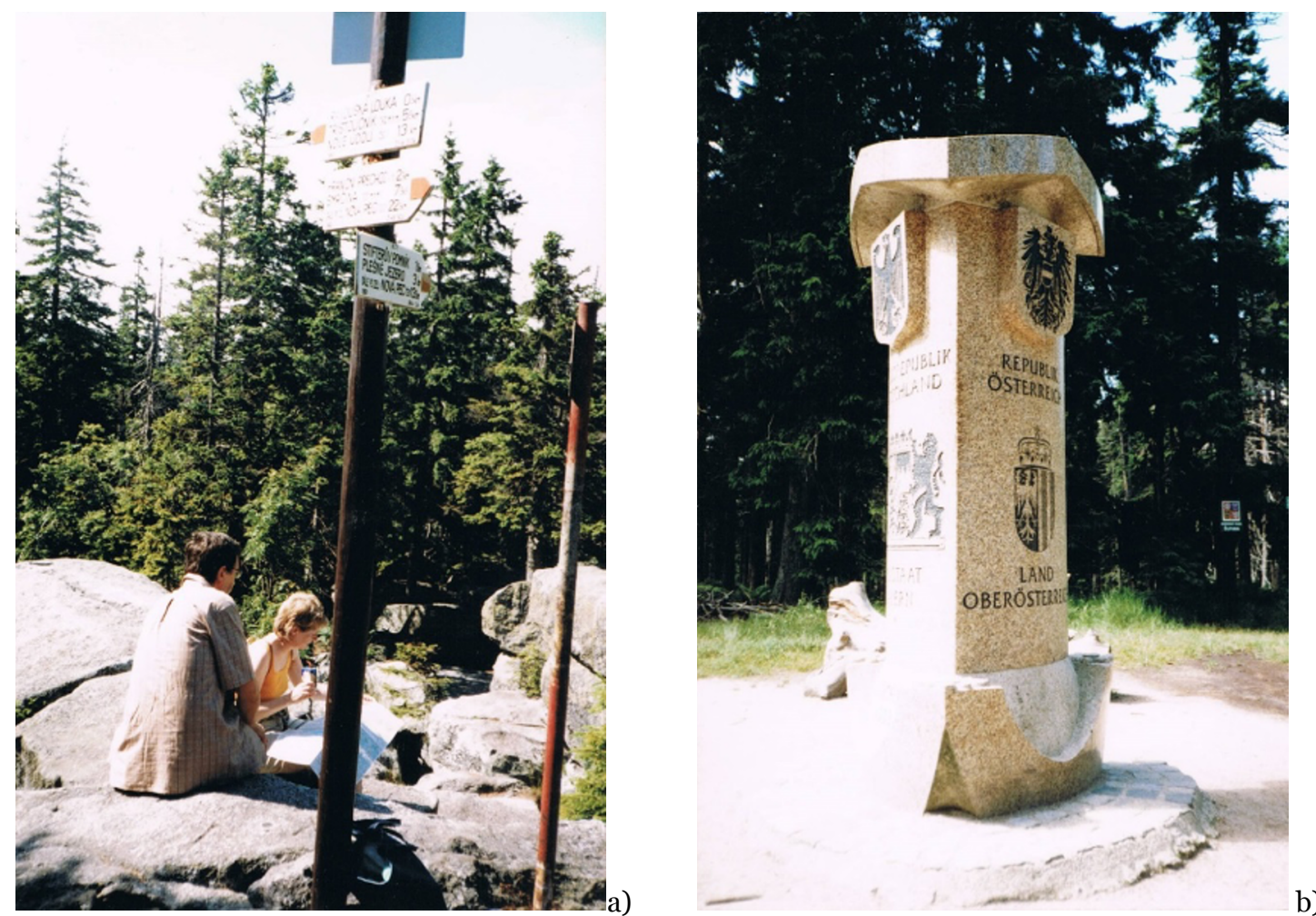

Figure 4 a) Signposts for hiking trails in 2002 at the Czech-Austrian tourist border crossing Plešné jezero Holzschlag I/3-10, located at the top of Plechý mountain; b) Monument at Trojmezí - the meeting point of the Czech Republic, Germany and Austria (photos: author 2002).

smaller number of points allowing the border to be crossed in the northwestern part are associated primarily with the existence of the German national park next to the Czech one, therefore a significant part of the border zone is strictly protected and the movement of tourists is limited. In addition, on the Czech side the settlement network is very poorly developed because in the communist period it was a military training area (after World War II, the German population was displaced, followed by very limited Czech settlement; Breuer et al. 2010). Given the small number of border crossings to which tourist trails have led from both sides and considering the 2.5 and $5 \mathrm{~km}$ concentric circles, in 2002 opportunities for crossing the border with the help of marked tourist trails were very limited, slightly better only in the southeastern part of the Sumava National Park.

Currently, the number of places where the state border in Šumava can be crossed based on tourist trails is much higher (Figure 5). On the section of the border, where the Czech national park is located, 19 have been inventoried where the routes of neighboring countries meet (16 on the Czech-German border and 3 on the much shorter Czech-Austrian section), additionally two more are in close vicinity to the park ( $0.5 \mathrm{~km}$ southeast and 3 $\mathrm{km}$ northwest). Furthermore, taking into account only the Czech national park, Czech marked routes were brought to the border in three more places, German in two, and Austrian in one, and on the other side of the border it is possible to continue a journey with an unmarked path. Although the offer is currently quite extensive, it is noticeable that there is a clear disproportion between the northwestern and southeastern parts of the national park. From Bučina to the vicinity of Prašily, a distance of about $20 \mathrm{~km}$, there is no place where the routes meet on both sides. This is similar to 2002 owing to the presence of national parks and core zones on both sides of the border with limited tourist accessibility. Considering the concentric circles, from most of the southeastern part of the park places where it is possible to cross the state border can be reached in two hours (sometimes the range of the $5 \mathrm{~km}$ concentric circle extends beyond the park), in the northwest part 


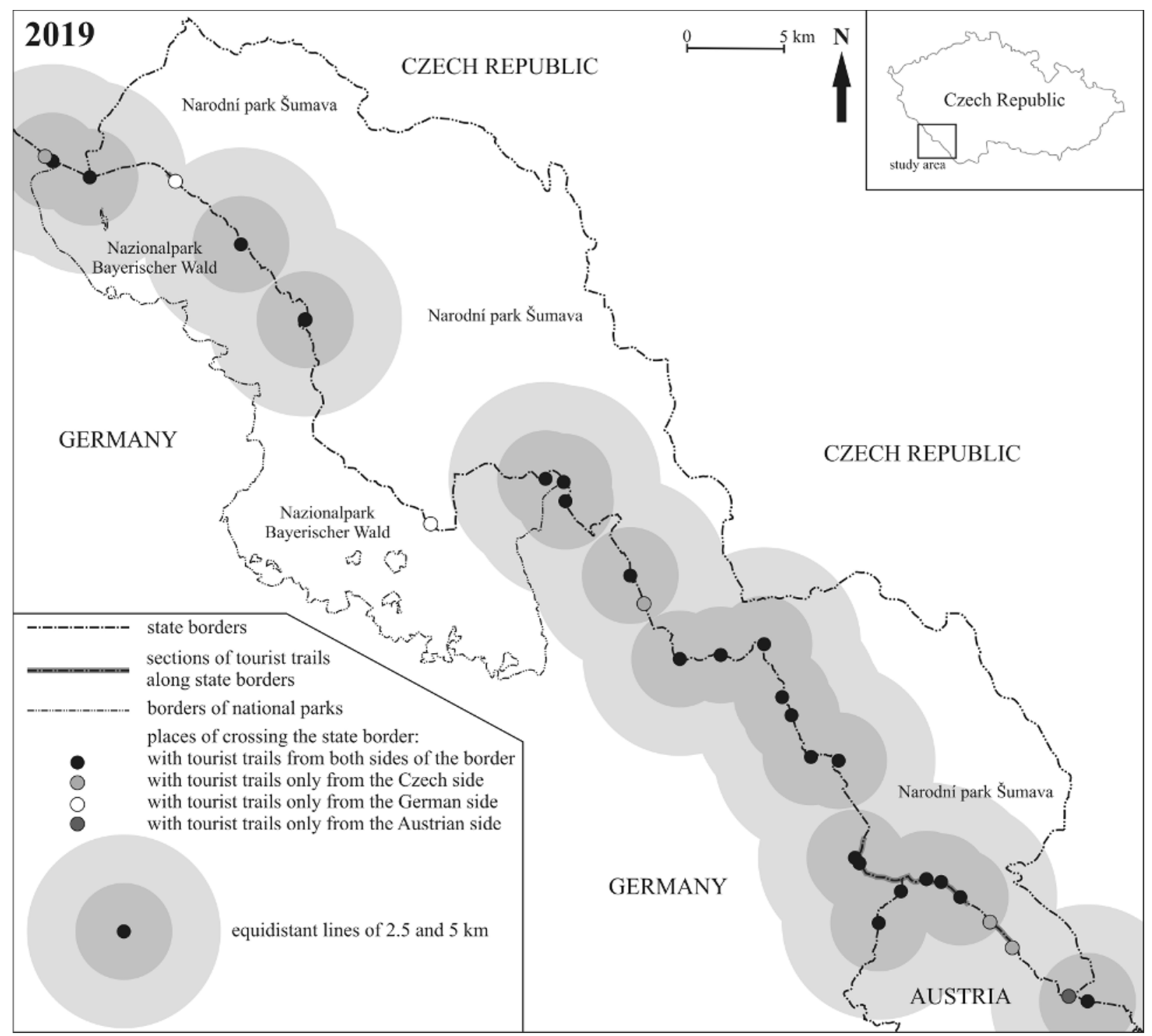

Figure 5 Crossing places on the Czech Republic border using tourist trails in Šumava and Bayerischer Wald National Parks in 2019.

this is still quite limited.

Considering the protection zones of the Czech national park (Dickie et al. 2014; Křenová and Hruška 2012), tourist trails leading to the state border only exceptionally run through the first, core zone, in which movement is possible only on marked trails. In addition, new sections, designated between 2002 and 2019, rarely enter its area, at most they lead along the border of the first zone. In general, within the entire national park there are relatively few sections within the core zone, hence it can be said that the role of tourist trails in providing access to legally limited areas is considerably small. In Šumava National Park, outside the first zone tourists can move along any path, hence the marked trails are only suggestions for them. The trails in the German national park, in which the strict protection zone extends along almost the entire length of the state border, are of greater importance in this respect. All trails must therefore cross the core zone to lead to the Czech network. Nevertheless the networks of tourist trails on both sides of the state border in Šumava region can now be said to be integrated. The infrastructure related to crossing places has also been expanded, especially in locations where both national parks are adjacent (Figure 6). In addition to resting places, boards have been placed giving information about tourist attractions on both sides, about opportunities to continue a journey, as well 
as about the rules in force in the adjacent protected areas. There is also information on long-distance routes crossing the border.

\section{Case study - Mountain Ranges Surrounding the Kłodzko Basin}

The course of the Czech-Polish border is quite complicated, resulting mainly from the terrain, the layout of the major mountain ridges or (definitely rarer) valleys (Kolejka et al. 2015). It is worth adding that the course of the present border largely corresponds to the border established in 1742, then separating Austria and Prussia (Maron 2006). A characteristic section of this is the part where the current Czech Republic surrounds the territory of Poland from three sides, the so-called Kłodzko basin. In physical geographic terms, this is the eastern part of the Central Sudeten mountains and the western East Sudeten mountains (Kondracki 2000), and the course of the border is an ideal example of reference to terrain (Kolejka et al. 2015). In the northwest it runs partly along the morphological edge of the Table Mountains and the hills of the Orlické/Orlickie Foothills, in the southwest along the main ridge of the Orlické/Orlickie Mountains, and further south along the course of the Divoká Orlice/Dzika Orlica river, which separates the Orlické and Bystrzyckie Mountains. In the southeast, the course of the border is along the main ridges of the Sněžník/Śnieżnik Massif, and in the northeast the main ridge of the Rychlebské/Złote Mountains. Historically, the Kłodzko basin had been a Bohemian domain from the $12^{\text {th }}$ century, was made
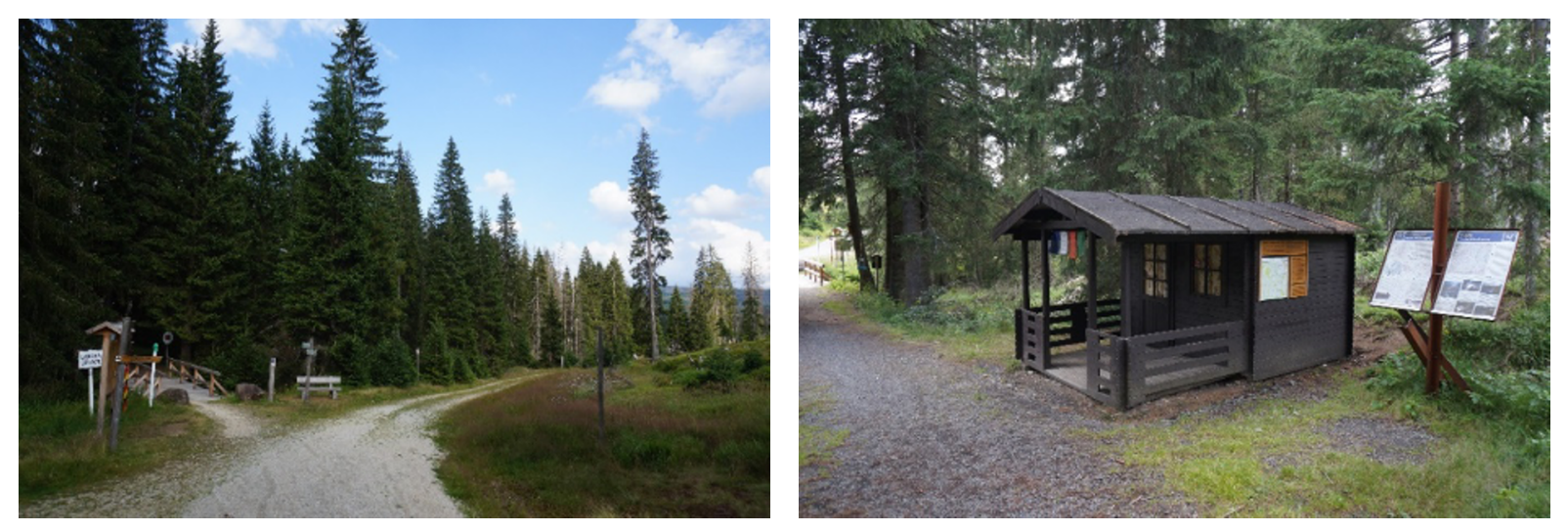

Figure 6 Tourist infrastructure (resting places, information boards) at the former tourist border crossing point Gsenget $\mathrm{u}$ Prašil - Scheuereck; the cabin is a former shelter for border guards (photos: author 2019). the County of Kladsko in 1459, later being part of Austria and Austro-Hungarian empire. The region was conquered by Prussia in the First Silesian War of 1740-1742 and incorporated into the Province of Silesia by 1818 . After World War II it became part of the Republic of Poland according to the 1945 Potsdam Agreement (Herzig and Ruchniewicz 2006; Martynowski and Mazurski 1988; Semotanová and Felcman 2005). Nowadays, the Kłodzko basin is an attractive tourist area, especially when it comes to natural attractions, and the border area (the highest in the region) is particularly abundant in scenery (Czerwiński 2009; Martynowski and Mazurski 1988; Migoń 1998; Myszkowska 2007). On the Polish side two protected areas are located, both adjacent to the border: 1) the Table Mountains National Park, whose equivalent on the Czech side is the Broumovsko Protected Landscape Area (both sandstone landscapes), and 2) the Śnieżnik Landscape Park. To allow admiring a view on two peaks on the state border lookout towers were built (Borůvková hora in the Rychlebské Mountains, Klepý in the Sněžník Massif); near the border there are also natural viewpoints, e.g. Bor in the Broumov Walls.

The Kłodzko basin and the surrounding peaks belong to areas where tourism began its earliest development. Probably the first licensed mountain guide in Europe was Franz Pabel (decision of the Prussian emperor from 1813) who led tourists to Szczeliniec Wielki (919 m), the highest peak of the Table Mountains. Thus, hiking has long traditions here, and the network of trails before World War II was one of the densest in the Sudeten mountains (along with the Giant Mountains; Dudziak and 
Potocki 1995; Potocki 2004). After 1945, it was significantly reduced, resulting from Czechoslovakia and Poland being in the so-called communist bloc, but this affected the Polish side more (Mazurski 2012; Staffa 1981). As mentioned above, the border zone was inaccessible or difficult to reach (Latocha 2012). However, it was in this area that the first deviations were introduced, for instance in Poland a new route was marked near the border making the eastern end of the Kłodzko basin available in 1956. In 1965-1967 the first short section of a hiking trail was marked along the border, leading to the summit of Śnieżnik, and in 1971-1975 it was significantly extended (Dudziak and Potocki 1995; Mazurski 2012). These factors meant that during the systemic transformation the networks of hiking trails on both sides were already fairly well-developed, however crossing the border was possible only at two road crossings which, however, were not connected to any marked trail. Therefore it is difficult to talk about network integration because along many sections, especially in the eastern part of the Kłodzko basin, two routes were marked, Czech and Polish, which could not be formally joined (although tourists often crossed the border illegally in such situations). The attractiveness of the region, however, meant that in the 1990 and at the beginning of the $21^{\text {st }}$ century, numerous tourist border crossings were successively created, some of which were adjacent to existing trails but new routes were also introduced. It was also the period of creating

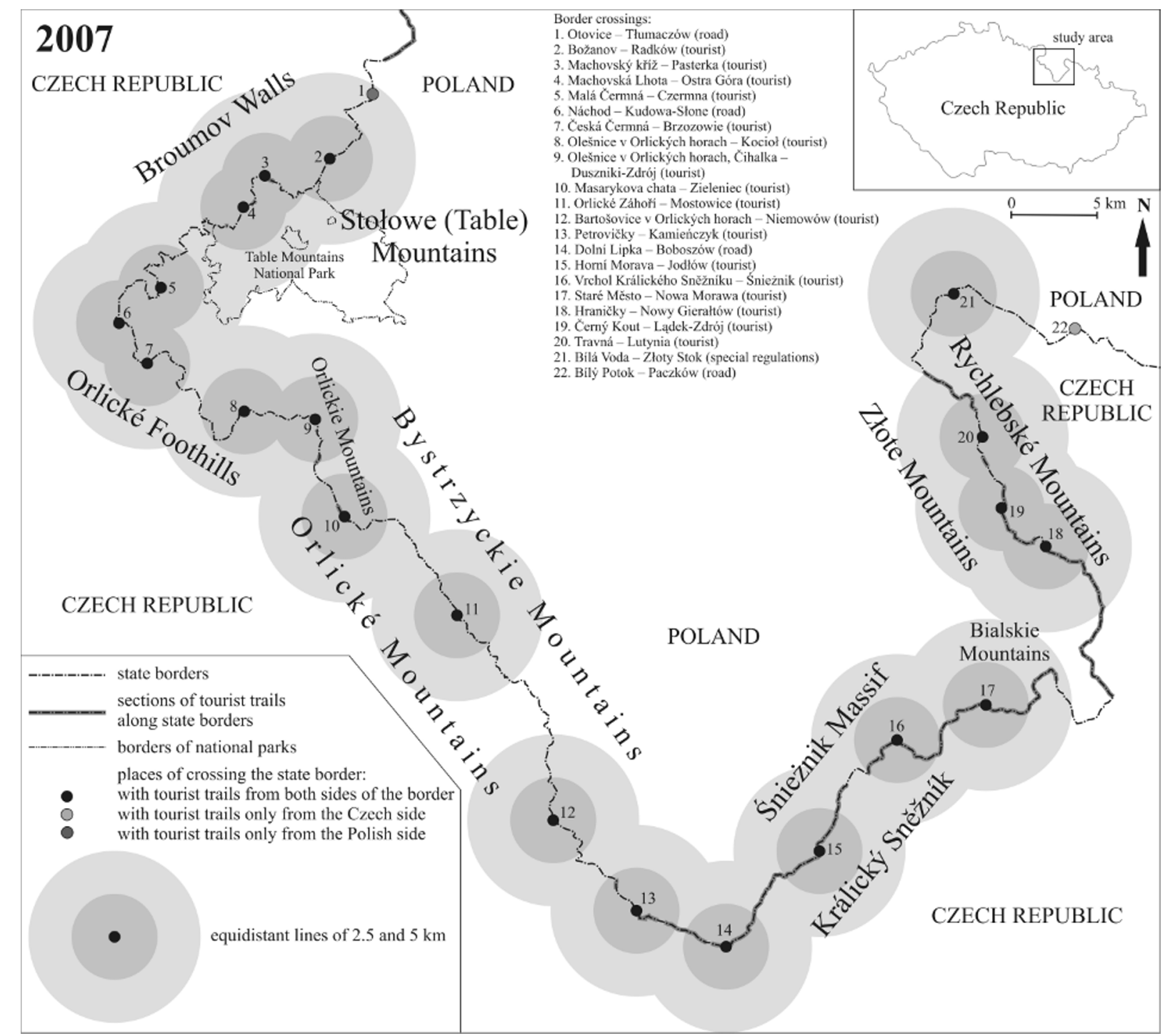

Figure 7 Crossing places on the Czech Republic border using tourist trails in the mountain ranges surrounding the Kłodzko basin in 2007. 
cycling trails which from the beginning were associated with tourist and road crossings. Everything resulted in the situation presented in Figure 7, just before both countries entered the Schengen area. A cursory view already indicates that in 2007 the possibilities for crossing the border based on tourist trails were much better in the Kłodzko region than in the Šumava region (Figure 3) and were almost comparable to the present state in Šumava (Figure 5).

In 2007, within the mountain ranges surrounding the Kłodzko basin, there were 20 places where it was possible to cross the border thanks to tourist trails reaching a certain point from both countries (Figure 7). In two cases these were road border crossings (Náchod - KudowaSłone and Dolní Lipka - Boboszów), in others tourist crossings or open according to the regulations of the so-called small border traffic (e.g. Bílá Voda - Złoty Stok). Additionally, a Polish hiking trail reached the border in one place, and a Czech one in another, but both places were located quite peripherally at the foot of the mountain ranges and did not have much importance (in both cases these were road border crossings, Otovice Tłumaczów and Bílý Potok - Paczków respectively). On the analyzed section of the border, however, there were no crossings without a connection to the network of tourist trails. The largest number of places where crossing was possible was in the western part of the Kłodzko basin, which corresponds to the tourist attractiveness of the area (apart from the Polish national park and the Czech protected landscape area with sandstone landscapes with numerous rock forms and viewpoints on both sides of the border, there are spas and many cultural attractions, including the castle of Náchod). There were fewer such places in the southwestern part, but this was due to the course of the border along the Divoká Orlice/Dzika Orlica river and the creation of tourist crossings only on the two bridges available there at the time (Orlické Záhoří - Mostowice and Bartošovice v Orlických horách - Niemojów). This offer has changed little for the same reason. Slightly fewer places to cross the border using tourist trails were found in the eastern part of the Kłodzko basin. The Bialskie Mountains located there, part of the Zlote
Mountains (equivalent of the Czech, Rychlebské hory), belonged for a long time to the least known and least visited Sudeten mountain ranges, and the network of trails was poorly developed. The reason was primarily their peripheral location. Only in recent years have new routes been marked.

Currently, there are 52 places where the tourist trails of both countries meet on the state border, which is over 2.5 times more than in 2007 (Figure 8). Most are located in the northwestern, western and eastern parts of the Kłodzko basin, and the least in the southwestern part for the reasons presented above (although two crossings have been introduced there since 2007). The number of places where tourist trails cross the border has clearly increased in the Table Mountains, but not only on the section of the border to which the Polish national park adjoins. Throughout its entire area tourism is allowed only on marked tourist trails, hence entry to the Schengen area, together with an absence of new routes, could not increase the openness of the border. The number of crossing points within the park has increased from 2 in 2007 to 5 in 2019 (Figure 9). Additional crossings, however, were created further west, where tourists can use a hiking trail that crosses the state border as many as four times (Kołodziejczyk 2014a). Many routes leading to the border have been marked in the Orlické Foothills. This was possible due to the high activity of a local institution managing the network of hiking trails which has contributed to its significant development in recent years (Kołodziejczyk 2019b). The area of the Orlické Foothills has considerable scenic value associated with non-forested hills, and because the state border usually leads through their highest parts, many marked trails run along it. In the vicinity, however, the situation on the Vrchmezi/Orlica Mountain (1084 m) ${ }^{5}$, the highest Polish summit of the Orlickie Mountains and one of the highest in their Czech part, is surprising. At the time of entry to the Schengen area, both the Czech and Polish trails ran below the summit, without joining. After 2007, the course of the Polish trail was changed slightly in such a way that it crossed the state border twice, leading through the summit and connecting with the Czech trail. After a few years,

${ }^{5)}$ The border runs approx. $30 \mathrm{~m}$ east from the summit. 


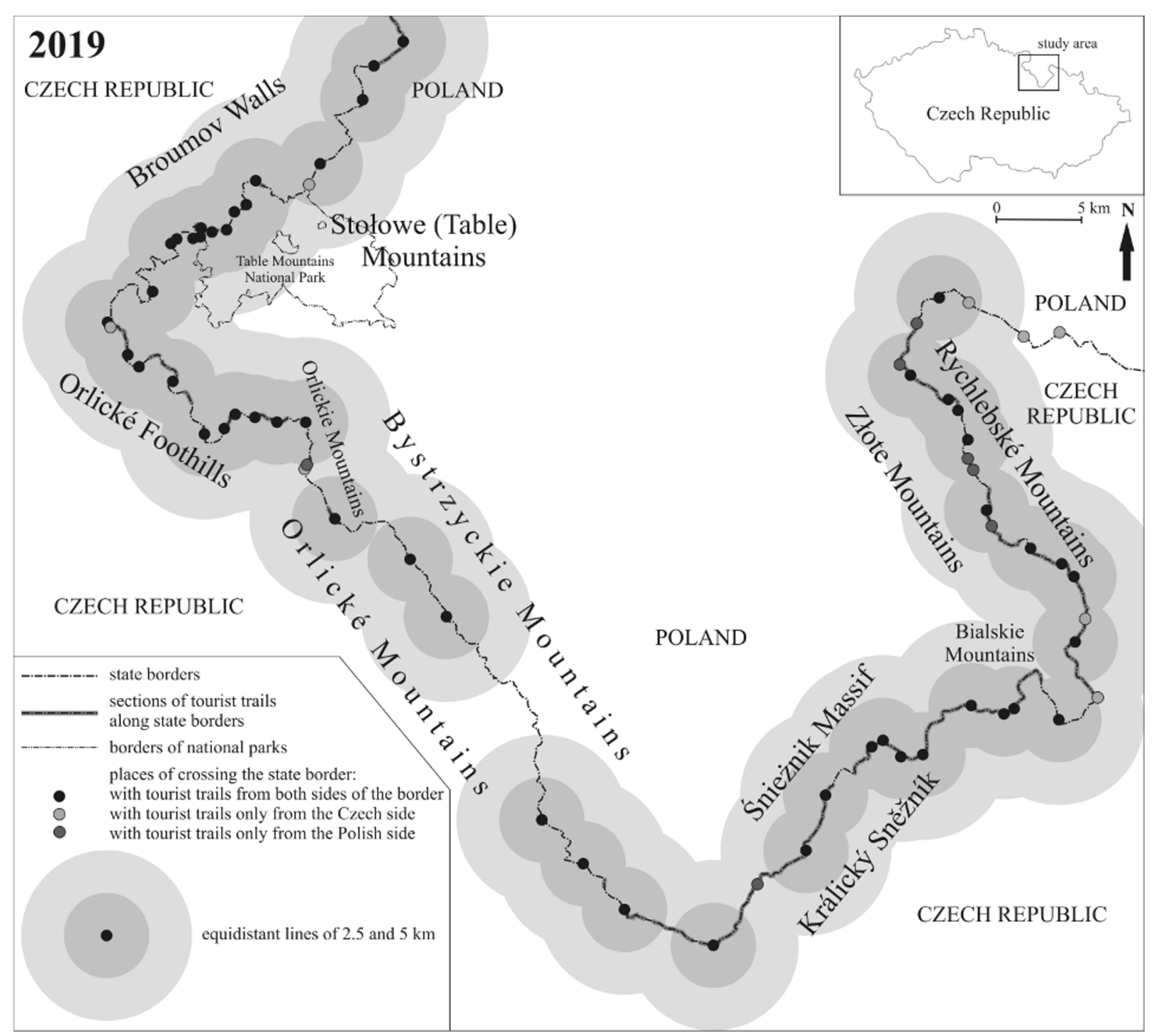

Figure 8 Crossing places on the Czech Republic border using tourist trails in the mountain ranges surrounding the Kłodzko basin in 2019.

however, the Polish trail returned to its course from before 2007, the short Czech side route now reaches the summit and again there is no connection between the Czech and Polish networks. Such a situation is quite atypical and undesirable, but may result from the fact that the Polish trail needs to fit to relief, roads network and border in the same time (as the summit is formally situated on the Czech side), while the Czech route is dependent almost exclusively on relief conditions. On the whole section of the border surrounding the Kłodzko basin there are a total of eight places, where the Czech route was marked to the border and has no continuation on the Polish side, and there are six Polish routes without a Czech equivalent. Thus there is a potential for further network integration.

The availability of points for crossing the state border on tourist trails is currently quite high. This can be determined by referring to the 2.5 and $5-\mathrm{km}$ concentric circles from the places where trails from both countries meet (compare Figures 7 and 8). When in 2007 the $2.5-\mathrm{km}$ concentric circles were mostly isolated, quite rarely touching each other or connecting, in 2019 they form an almost continuous zone except for the southwest and south of the region (the consequence of, respectively, the impact of the Divoka Orlice river, which forms the border, and the lower attractiveness of the area which results in a less 

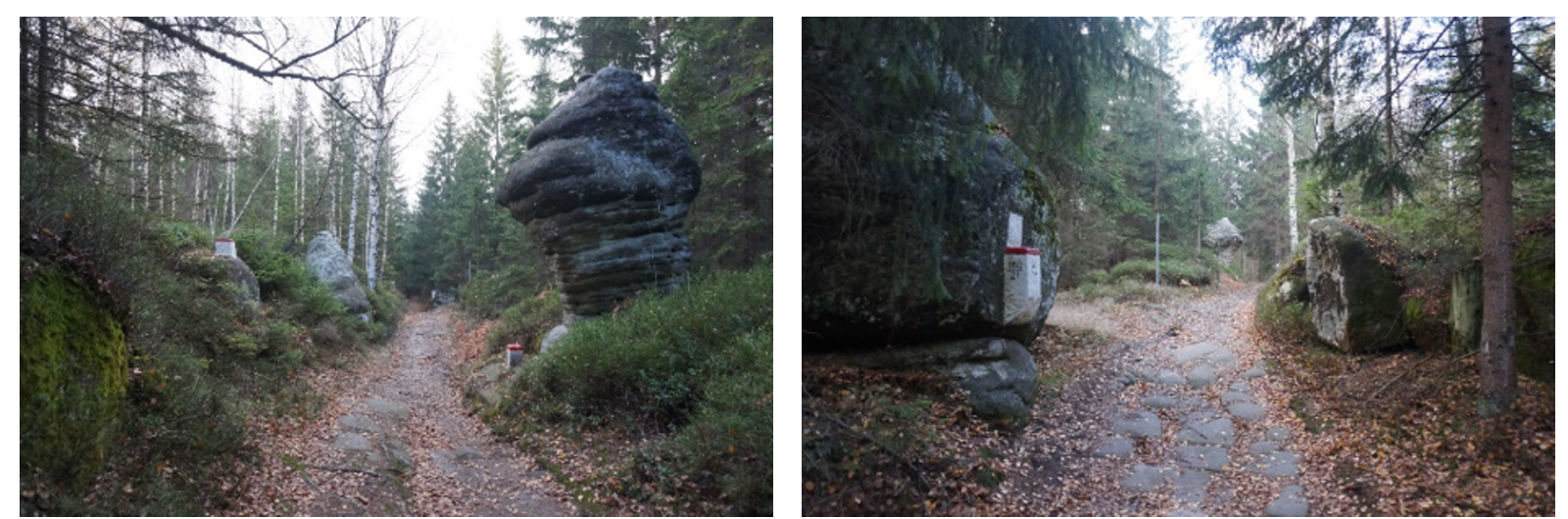

Figure 9 A section of a hiking trail leading along the state border within the Table Mountains National Park (photos: author 2018).
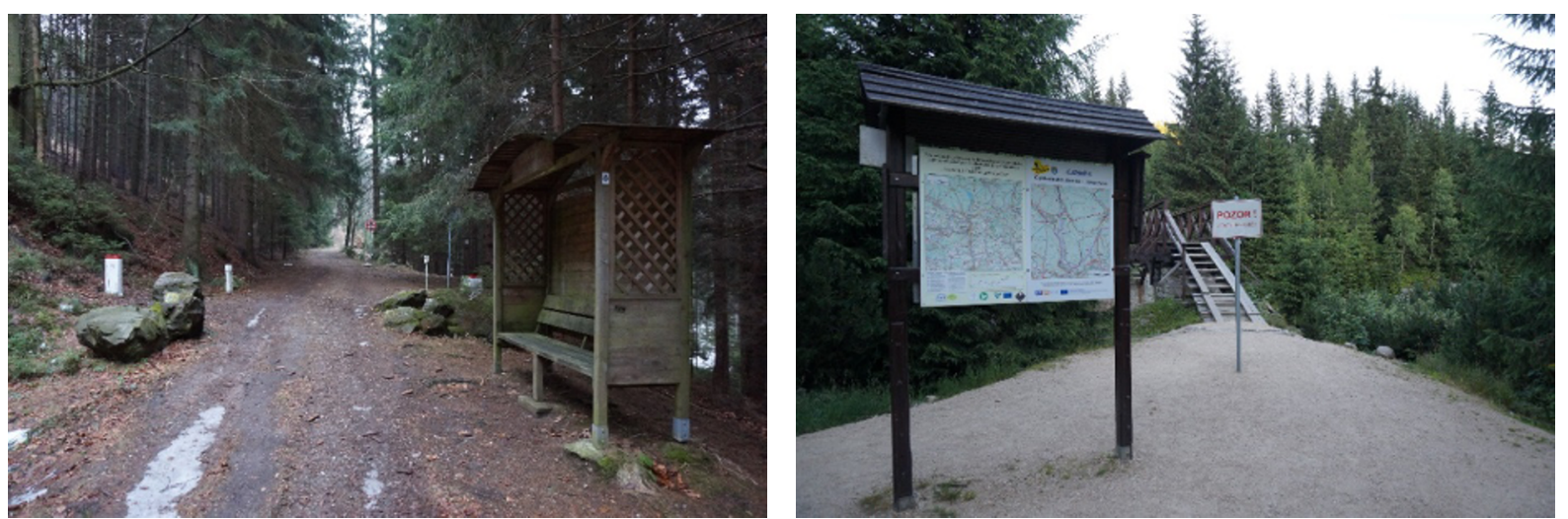

Figure 10 Examples of tourist infrastructure at places where the state border is crossed by tourist trails in the Central and Western Sudeten mountains: former tourist border crossings (photos: author 2018, 2019).

developed network of tourist trails). Currently, a continuous zone with only one break (in the valley of the Divoka Orlice) is created by the $5-\mathrm{km}$ concentric circle. Therefore, being near the state border and using the network of tourist trails, within one hour (exceptionally two) a place where this border can be legally and comfortably crossed should be reached. This is a period of time that allows a trip to be made into a neighboring country and a return to the place of accommodation. As for tourist infrastructure, in the Kłodzko region, unlike Šumava, it was developed on a larger scale before 2007. Tourist border crossings were equipped with resting places (shelters, tables, benches, litter bins), information boards, signposts, sometimes even parking lots. Places of crossing the borders created after the extension of the Schengen area are no longer so richly equipped, perhaps because there are quite a lot of them and there is no such concentration of tourists. Signposts appear in such places, sometimes an information board, but some have no facilities at all (of course, except for the marking of tourist trails).

\section{Discussion}

Tourist trail networks in many mountain ranges are considered to be fully developed, for example, hiking trails in the Polish Sudeten mountains were already considered so in the 1980 s (Staffa 1985, 1986). However, various factors may result in the network of trails not being sufficiently developed or meeting the needs of tourists, local communities and nature conservation. These include new phenomena and trends in tourism as well as changes in the natural environment and tourism development, for example Mazurski (2012) associated the need to rebuild the network of hiking trails in the Polish mountains with a change in the model of tourism with an abandonment of longer, several-day hiking with backpacks in favor of shorter, round trips with minimal equipment (compare Potocki 2004). Factors affecting the 
shape of the network of tourist trails include political issues, such as the accessibility of the border zone and the possibility of crossing a state border, as presented in this article. Shown in this and other articles (including Kołodziejczyk 2014a, 2015b; Potocki 2013), the entry of Central European countries into the Schengen area has resulted in the integration of a network of official trails on both sides of the borders. Kołodziejczyk (2014a) for the Polish-Czech border has indicated that changes in the network and the course of particular trails after entry were limited to certain areas and less numerous than those resulting from the opening of tourist border crossings before 2007 . From a perspective of more than a decade since the enlargement of the Schengen area these changes should be considered significant and, what may be more important, continuing. It should also be remembered that the network development in the period from the systemic transformation in Central Europe at the beginning of 1990 s to 2007, as a result of opening subsequent border crossings of various types, largely filled the previous gap by creating many missing connections. Therefore, when the borders were made fully open, there was not always a need to complement the connections within networks. Later work (e.g. Kołodziejczyk 2019b) confirms that the development of the network, at least locally, is progressing and the scope for change is clearly greater than in the first years after the expansion of the Schengen area. Kołodziejczyk (2014a) stated that the network of tourist trails along the Polish-Czech border in the Sudeten mountains cannot be considered final and coherent. At present, for some mountain ranges, it can be assumed that such coherence has already been achieved (e.g. the Orlické Foothills, Table Mountains, southeastern part of Šumava, and the Lusetian Mountains; see Kołodziejczyk 2017). On the other hand, it should be remembered that providing new tourist routes and areas should not violate the principles of sustainable development and integrated tourism development (Arcuset 2009; Buckley 2012; Bousset et al. 2007; Kušová et al. 2008; Moyle 2013; Neto 2003; Sharpley 2000).

In addition to integrating the network of tourist trails, in a situation of full openness of state borders in Central Europe, a common tourist infrastructure can be considered for routes running along or in the vicinity of borders. Staffa (1981) pointed this out at the beginning of the 1980s, although for political reasons this idea could not be fully realized in that time. Looking at the duplication of shelters on both sides of the border in the Giant Mountains, he proposed the implementation of joint Polish-Czechoslovak investments, including view-towers, signposts, information boards, resting places, which has to some extent been implemented (Figure 10). However, Staffa (1981) mentioned also common energy, water supply and sewage treatment plants for shelters and other facilities, which has not happened so far. The contemporary opening of state borders and the strengthening of cross-border cooperation has increased opportunities and there can be common resting points and shelters, usually located in places of border crossings, preferably equipped with boards with tourist maps and bilingual information about nearby tourist attractions in both countries (Kołodziejczyk et al. 2014). Often, such infrastructure has been created thanks to EU funds as part of joint local government initiatives from both sides of the border. The unequivocal manifestation of a full integration of the network of routes of neighboring countries should be common signposts in places where trails converge. Before this, however, the names of the border nodes should be unified.

The processes discussed are part of the wider phenomenon of integration on state borders, analyzed for example for the Polish-Czech and Polish-German borders by Dołzbłasz (2012, 2017a), Dołzbłasz and Raczyk (2015, 2016), Johnson (2009) and Raczyk and Leśniak-Johann (2012). This integration has taken place with varying success on various levels, but tourism is one aspect in which cooperation is particularly intense (Dołzbłasz 2017b; Więckowski 2010). The topics discussed also include openness, but it is more about the openness of business entities on both sides to cooperate with their foreign counterparts, although indirectly this is also an expression of the level of openness of the border (Dołzbłasz 2015; Dołzbłasz and Raczyk 2012).

\section{Conclusions}

The entry of Central European countries into the Schengen area has contributed to the 
development of the tourist trail network and to the improvement of their integration on both sides of the border. The article shows the example of the borders of the Czech Republic with all its neighbors, of which the vast majority run through areas with mountain relief. The number of places where the tourist trails of neighboring countries converge over a decade after the extension of the Schengen area has clearly increased, and in addition to the existing crossings of various types, more such places have appeared using favorable terrain and the layout of existing roads and paths. This was shown in the example of the two research areas, but is also confirmed by publications analyzing trail networks in other areas, as presented above. In the case of the borders of the Czech Republic, crossing is more often made possible using hiking trails than cycling routes, but this is due to the general density of networks of these two types of trails in mountainous areas. The varied terrain does not always allow a cycling route to be marked, especially in the highest parts of mountain ranges where the state border runs. Hiking trails cross the border every $7.91 \mathrm{~km}$, while cycling routes every $13.3 \mathrm{~km}$, but considering the speed of movement, it can be said that the openness of the border for bicycle tourists is higher than for hikers. Moreover, there are various other factors influencing the development of tourist trails, popularity of certain activities being among the most important, and it has to be remembered that mountain biking developed quite rapidly in the region in last years. As for individual neighbors of the Czech Republic, the Czech-Slovak and CzechPolish borders are characterized by the highest degree of integration of hiking trails, while for cycling routes, the Czech-Austrian and Czech-Slovak sections are the most open. The close integration of both types of trails between the Czech Republic and Slovakia has historical roots, until 1992 they constituted one state and the network had been developed as a whole. The relationship between them has remained strong, as evidenced by numerous border crossings.

As shown in the article, in many places there is still significant potential for a further integration of tourist trail networks, sometimes the trails of neighboring countries run close to the border and it is enough to designate a connecting route between them, in other situations trails created in one country do not have a continuation on the other side, although the possibility exists. This problem applies to both the Czech Republic and all its neighbors, because, depending on the type of trail and the section of the border, a greater frequency of such situations applies to just one side. It should be emphasized, however, that full network integration often requires not only the designation of several new trails (connectors) but a significant reconstruction of the trail system. This is especially important in protected areas such as national parks, where trails create often the only opportunity for tourist penetration. In such areas nature protection regulations prevail over border regulations, so the border cannot be crossed anywhere. Thus, it can be said that currently the right relationship between natural and human factors affecting the development of the trail network has been restored in the analyzed areas. After four decades of the dominant role of the political factor (restrictions in access to the border area), natural issues again have a decisive role. This is especially important in mountainous areas, where it is natural factors, especially the terrain, density of vegetation cover and the occurrence of wetlands that affect the course of tourist trails.

The article uses two indicators that characterize two aspects of integration of the tourist trail network. Although the more general one (reflecting the openness of the border) seems more important, the second one (analyzing lack of continuation in a form of a marked trail on the other side of the border) should also be taken into consideration as it shows the current network potential for further integration, i.e. where new routes leading to the border should be planned. Given the coherence of the network and the openness of the border, a minimum number of places where tourists cannot find a continuation of their trail on the other side of the border is desirable. The next step may be an attempt to combine these two indicators into one that would comprehensively determine the degree of integration of the tourist trail network on both sides of the borders.

\section{Acknowledgements}

The study was funded by the University of Wroclaw (Grant no. 0420/2667/18). 


\section{References}

Anderson J, O’Dowd L (1999) Borders, border regions and territoriality: contradictory meanings, changing significance. Regional Studies 33: 593-604. https://doi.org/10.1080/00343409950078648

Arcuset L (2009) Possible paths towards sustainable tourism development in a high-mountain resort. Journal of Alpine Research/Revue de Géographie Alpine 97(3): 1-13. https://doi.org/10.4000/rga.1048

Buckley R (2012) Sustainable tourism: research and reality. Annals of Tourism Research 39(2): 528-546. https://doi.org/10.1016/j.annals.2012.02.003

Bousset JP, Těšitel J, Skuras D, et al. (2007) A decision support system for integrated tourism development: rethinking tourism policies and management strategies in the Czech Republic, France and Greece. Tourism Geographies 9: 387404.

Breuer T, Kolejka J, Marek D, Werner E (2010) Convergence of cultural landscape on the Czech-Bavarian border in Sumava Mts. Geografie 115(3): 308-329.

Bukała A (2011) Szlaki turystyczne jako wybrany element zagospodarowania turystycznego Gór Opawskich - stan obecny i możliwości rozwoju [Tourist trails as a selected element of tourist infrastructure in the Opawskie Mountains - present state and development perspectives]. In: Chrobak $\mathrm{P}$, Szymkowicz P (eds.), Transgraniczny Potencjał Turystyczny Gór Opawskich: Materiały Konferencyjne [Transborder Tourist Potential of the Opawskie Mountains: Conference Materials]. Głuchołazy: Gmina Głuchołazy, pp 5-14. (In Polish)

Ceballos-Lascuráin H (ed.) (1996) Tourism, Ecotourism, and Protected Areas: the State of Nature-based Tourism around the World and Guidelines for its Development. IV World Congress on National Parks and Protected Ares. GlandCambridge: IUCN, The World Conservation Union, IUCN Protected Areas Programme.

Celata F (2007) Geographic marginality, transport accessibility and tourism development. In: Celant A. (ed), Global Tourism and Regional Competitiveness, Bologna: Patron, pp 37-46.

Chmiel J (2011) Historia znakowania szlaków turystycznych na pograniczu nysko-jesenickim [History of hiking trails marking in the Nysa - Jeseník borderland]. In: Chrobak P, Szymkowicz P (eds.) Transgraniczny Potencjał Turystyczny Gór Opawskich: Materiały Konferencyjne [Transborder Tourist Potential of the Opawskie Mountains: Conference Materials]. Głuchołazy: Gmina Głuchołazy, pp 63-67. (In Polish)

Czerwiński J (2009) Dolny Śląsk: Przewodnik [Lower Silesia: Guide], Wroclaw: Wydawnictwo Kartograficzne Eko-Graf. (In Polish)

Dickie I, Whiteley G, Kindlmann P, Křenová Z, Bláha J (2014) An outline of economic impacts of management options for Šumava National Park. European Journal of Environmental Sciences 4(1): 5-29. https://doi.org/10.14712/23361964.2015.1

Dokoupil J, Kopp J, et al. (2011) Vliv Hranice na Př́rodní a Socioekonomické Prostředí Českobavorského Pohraničí [Influence of the Border on the Natural and Socio-economic Environment of the Bohemian-Bavarian Borderland]. Plzeň: Západočeskáuniverzita v Plzni. (In Czech)

Dołzbłasz S (2012) Transborder relations between territorial units in the Polish-German borderland. Geographia Polonica 85: 23-36. https://doi.org./10.7163/GPol.2012.3.16

Dołzbłasz S (2015) Symmetry or asymmetry? Cross-border openness of service providers in Polish-Czech and PolishGerman border towns. Moravian Geographical Reports 23(1): 2-12. https://doi.org/10.1515/mgr-2015-0001

Dołzbłasz S (2017a) Sieci Współpracy Transgranicznej na Pograniczach Polski [Cross-border Cooperation Networks on the Polish Border]. Wroclaw: Uniwersytet Wrocławski. (In
Polish)

Dołzbłasz S (2017b) Transborder tourism in the Polish-Czech borderlands. In: Hall D (ed.), Tourism and Geopolitics: Issues and Concepts from Central and Eastern Europe. WallingfordBoston: CABI, pp 163-177.

Dołzbłasz S, Raczyk A (2012) Transborder openness of companies in a divided city: Zgorzelec/Görlitz case study. Tijdschrift voor Economische en Sociale Geografie 103: 347361. https://doi.org/10.1111/j.1467-9663.2011.00688.x

Dołzbłasz S, Raczyk A (2015) Different borders - different cooperation? Transborder cooperation in Poland. Geographical Review 105(3): 360-376.

https://doi.org/10.1111/j.1931-0846.2015.12077.x

Dołzbłasz S, Raczyk A (2016) Transborder co-operation and competition among firms in the Polish-German borderland. Tijdschrift voor Economische en Sociale Geografie 108(2): 141-156. https://doi.org/10.1111/tesg.12191

Dudek T (2017) Recreational potential as an indicator of accessibility control in protected mountain forest areas. Journal of Mountain Science 14(7).

https://doi.org/1419-1427. 10.1007/s11629-016-4018-z

Dudziak T, Potocki J (1995) Rozwój sieci szlaków turystycznych w Sudetach [Development of the network of tourist trails in the Sudeten mountains]. Śląski Labirynt Krajoznawczy 7: 99118. (In Polish)

ExpressMap (2007) Sudety Wschodnie: Mapa Laminowana 1:120 00o [Eastern Sudeten Mountains: Laminated Map 1:120 ooo]. Warsaw: Wydawnictwo Kartograficzne ExpressMap Sp. z o.o. (In Polish)

Faracik R (2008), Główne regiony turystyczne świata [Main tourist region of the world]. In: Kurek W (ed.), Turystyka [Tourism]. Warsaw: Wydawnictwo Naukowe PWN, pp 87-121. (In Polish)

Geodézie On Line (2014) Šumava - Trojmezí: Cykloturistická a Turistická Mapa 1:25 ooo [Šumava - Trojmezí: Cyclotourist and Tourist Map]. Ceská Lipa: Geodézie On Line spol. s r.o. (In Czech)

Geodézie On Line (2018) Šumava - Pláně: Turistická, Cykloturistická a Lyžařská Mapa 1:25 000 [Šumava Trojmezí: Tourist, Cyclotourist and Skiing Map]. Česká Lipa: Geodézie On Line spol. s r.o. (In Czech)

Gorner T, Čihař M (2013) Local attitudes on protected areas: evidence from Šumava National Park and Šumava Protected Landscape Area. Environment and Pollution 2: 1-13. https://doi.org/10.5539/ep.v2n2p1

Górecka S, Toczak P (2008) Demographic development of Lower Silesia with particular focus on the Polish-Czech and Polish-German borderland. In: Sasek M (ed.), Social and Economic Development and Regional Politics. Usti nad Labem: Jan Evangelista Purkyne University, pp 50-61.

Herzig A, Ruchniewicz M (2006) Dzieje Ziemi Kłodzkiej [History of the Kłodzko Land]. Hamburg-Wrocław: Oficyna Wydawnicza Atut. (In Polish)

Illner M (1996) Post-communist transformation revisited. Sociologický časopis/Czech Sociological Review 4(2): 157-169.

Johnson CM (2009) Cross - border regions and territorial restructuring in Central Europe: room for more transboundary space. European Urban and Regional Studies 16(2): 177-191. https://doi.org/10.1177/0969776409102190

Kasprzak M, Migoń P, eds. (2012) Góry Stołowe: Geology, Landforms, Vegetation Patterns and Human Impact. Wroclaw: Department of Geography and Regional Development, University of Wroclaw.

Klaus V (2006) The economic transformation of the Czech Republic: Challenges faced and lessons learned. Economic Development Bulletin 6.

(https://www.cato.org/publications/economic-developmentbulletin/economic-transformation-czech-republic-challengesfaced-lessons-learned, accessed on 2019-07-15). 
Kolejka J, Żyszkowska W, Batelková K, Ciok S, Dołzbłasz S, Kirchner K, Krejčí T, Raczyk A, Spallek W, Zapletalová J (2015) Permeability of Czech-Polish border using by selected criteria. Geographia Technica 10(1): 51-65.

Kołodziejczyk K (2014a) Rozwój sieci szlaków turystycznych wzdłuż granicy polsko-czeskiej w Sudetach w latach 19452013 [Development of a network of tourist trails along the Polish-Czech border in the Sudeten mountains in the years 1945-2013]. Prace Geograficzne 136: 81-101. (In Polish) https://doi.org/10.4467/20833113PG.14.005.1643

Kołodziejczyk K (2014b) Singltrek pod Smrkem. Sudety. Przyroda, Kultura, Historia 2(155)/2014: 22-23. (In Polish)

Kołodziejczyk K (2015a) Wzorce Zagospodarowania Szlaków Turystycznych w Górach Średnich na Wybranych Przykładach Europejskich [Standards for Infrastructure on Tourist Trails in the Middle Height Mountains on Selected European Examples]. Wroclaw: Instytut Geografii i Rozwoju Regionalnego Uniwersytetu Wrocławskiego. (In Polish)

Kołodziejczyk K (2015b) Integracja sieci szlaków turystycznych wzdłuż granicy polsko-czeskiej w Sudetach po wstąpieniu Polski i Republiki Czeskiej do strefy Schengen [Integration of network of tourist trails along Polish-Czech state border in Sudeten mountains after Poland and Czech Republic joining the Schengen area]. In: Babińska $M$ (ed.), Turystyka na Pograniczu Polsko-Czeskim [Tourism on Polish-Czech Borderland]. Wałbrzych: Państwowa Wyższa Szkoła Zawodowa im. Angelusa Silesiusa, pp 85-98. (In Polish)

Kołodziejczyk K (2017) Organizacja ruchu turystycznego w Parku Krajobrazowym Gór Żytawskich [Organization of tourism in the Zittau Mountains Landscape Park]. Ekonomiczne Problemy Turystyki 37(1): 85-99. (In Polish) https://doi.org/10.18276/ept.2017.1.37-07

Kołodziejczyk K (2018) Sieć pieszych szlaków turystycznych w Parku Krajobrazowym Góry Izerskie w północnej Republice Czeskiej [Network of hiking trails in the Jizera Mountains Landscape Park in the northern Czech Republic]. Prace Geograficzne 152: 83-104. (In Polish)

https://doi.org/10.4467/20833113PG.17.032.8255

Kolodziejczyk K (2019a) Networks of hiking tourist trails in the Krkonoše (Czech Republic) and Peneda-Gerês (Portugal) national parks - comparative analysis. Journal of Mountain Science 16(4): 725-743.

https://doi.org/10.1007/s11629-018-5228-3

Kołodziejczyk K (2019b) Rozwój sieci szlaków pieszych w wybranych częściach Sudetów Srodkowych w latach 20052017 [Development of the network of hiking trails in selected parts of the Central Sudeten mountains in 2005-2017]. Prace Geograficzne 156: 9-33. (In Polish) https://doi.org/10.4467/20833113PG.19.001.10305

Kołodziejczyk K, Stasiak A, Śledzińska J, Włodarczyk A (2014) Szlaki turystyczne w Europie [Tourist trails in Europe]. In: Stasiak A, Śledzińska J, Włodarczyk B (eds.), Szlaki Turystyczne - od Pomysłu do Realizacji [Tourist Trails - from the Idea to the Implementation]. Warsaw: Wydawnictwo PTTK “Kraj”, pp 59-95. (In Polish)

Kondracki J (2000) Geografia Regionalna Polski [Regional Geography of Poland]. Warsaw: Wydawnictwo Naukowe PWN. (In Polish)

Kowalczyk A, Derek M (2010) Zagospodarowanie Turystyczne [Tourist Infrastructure]. Warsaw: Wydawnictwo Naukowe PWN. (In Polish)

Krakowiak B (1997) Zagospodarowanie turystyczne karpackich parków narodowych [Tourist infrastructure in the Carpathian national parks]. Turyzm 7(2): 25-44. (In Polish)

Kř̌enová Z, Hruška J (2012) Proper zonation - An essential tool for the future Conservation of the Sumava National Park. European Journal of Environmental Sciences 2: 62-72. https://doi.org/10.14712/23361964.2015.40

Křenová Z, Kiener H (2012) Europe's Wild Heart - still beating? Experiences from a new transboundary wilderness area in the middle of the old continent. European Journal of Environmental Sciences 2: 115-124. https://doi.org/10.14712/23361964.2015.32

Kušová D, Těšitel J (2016) The Šumava Biosphere Reserve historical reflection on institutional arrangements. Silva Gabreta 22: 99-109.

Kušová D, Těšitel J, Bartoš M (2008) Biosphere reserves learning sites of sustainable development? Silva Gabreta, 14: 221-234.

Latocha A (2012) Changes in the rural landscape of the Polish Sudety Mountains in the post-war period. Geographia Polonica 85,4: 13-21.

http://doi.org./10.7163/GPol.2012.4.21

Lijewski T, Mikułowski B, Wyrzykowski J (2002) Geografia Turystyki Polski [Tourism Geography of Poland]. Warsaw: Polskie Wydawnictwo Ekonomiczne. (In Polish)

Lindrová T (2018) Turistika $\mathrm{v}$ Krkonoších [Tourism in the Krkonoše Mountains]. Vrchlabí: Správa KRNAP. (In Czech)

Lokvenc T (2006) Romantické začátky turistiky [Romantic beginnings of tourism]. Krkonoše - Jizerské hory 39(6): 2224. (In Czech)

Maroń J (2006) Dolny Śląsk w czasach habsburskich i pruskich [Lower Silesia in Habsburgian and Prussian times]. In: Wrzesiński W (ed.), Dolny Śląsk: Monografia Historyczna [Lower Silesia: Historical Monography]. Wroclaw: Wydawnictwo Uniwersytetu Wrocławskiego, pp 226-260. (In Polish)

Martynowski Z, Mazurski KR (1988) Sudety: Ziemia Kłodzka i Góry Opawskie [Sudeten Mountains: Kłodzko Land and Opawskie Mountains]. Warsaw: Wydawnictwo Sport i Turystyka. (In Polish)

Mazurski KR (2012) Historia Turystyki Sudeckiej [History of Tourism in Sudeten Mountains]. Cracow: Oficyna Wydawnicza "Wierchy", COTG PTTK. (In Polish)

Migoń P (1998) Ziemia Kłodzka: Przewodnik [Kłodzko Land: Guide]. Wrocław: Eko-Graf. (In Polish)

Moyle B (2013) Managing outdoor recreation: case studies in the national park. Annals of Tourism Research 41: 244-266. https://doi.org/10.1016/j.annals.2013.02.011

Myszkowska B (2007) Sudety [Sudeten Mountains]. Warsaw: Hachette Livre Polska. (In Polish)

Neto F (2003) A new approach to sustainable tourism development: Moving beyond environmental protection. Natural Resource Forum 27: 212-222. https://doi.org /10.1111/1477-8947.00056

Pánek T, Hradecký J (eds) (2016) Landscapes and Landforms of the Czech Republic. Dordrecht: Springer.

Picek M, Růžička T, Silovský V, Těšitel J, Vlášková K (2007) Tourism in the Šmava Mountains: Concept of Sustainable Tourism Development. Action Programme. Issued by Regionální rozvojová agentura Šumava, o.p.s.

Plan (2007) Góry Stołowe: Mapa Turystyczna 1:30 ooo [Table Mountains: Tourist Map 1:30 ooo]. Jelenia Góra: Wydawnictwo Kartograficzne Plan. (In Polish)

Potocki J (2004) Rozwój Zagospodarowania Turystycznego Sudetów od Połowy XIX w. do II Wojny Światowej [The Development of the Tourist Infrastructure of the Sudeten Mountains from the mid-19th Century to the Second World War]. Jelenia Góra: Wydawnictwo Turystyczne Plan. (In Polish)

Potocki J (2010) Pressure on natural environment in major tourist locations of the Karkonosze Mts. in light of demographic trends and expansion of the tourist function of the region. Opera Corcontica 47, Suppl. 1: 277-282.

Potocki J (2013) Ksztaltowanie sieci turystycznych szlaków pieszych w Sudetach po II wojnie światowej i jego ważniejsze uwarunkowania [Shaping the network of tourist hiking trails in the Sudeten mountains after the Second World War and its more important conditions]. In: Mateusiak A. (ed.), Zarys Dziejów Turystyki i Przewodnictwa w Sudetach [Outline of the History of Tourism and Tourist Guidance in the Sudeten Mountains]. Jelenia Góra: Wydawnictwo AD REM, pp 23-46. (In Polish)

Ptaszycka-Jackowska D, Baranowska-Janota M (1989) Zasady 
Korzystania z Przyrodniczych Obszarów Chronionych [Rules for Using Protected Natural Areas]. Warsaw: Instytut Gospodarki Przestrzennej i Komunalnej. (In Polish)

Raczyk A, Leśniak-Johann M (2012) The competitive position of border areas in relation to the Polish and German regions. Geographia Polonica 85: 37-54.

http://doi.org./10.7163/GPol.2012.3.17

Rogowski M (2017) Mountain hiking in the Stołowe Mountains National Park. Tourism 27(2): 89-97.

Roszkowski W (2003) Najnowsza Historia Polski 1980-2002 [The Recent History of Poland 1980-2002]. Warsaw: Świat Książki. (In Polish)

Semotanová E, Felcman O (2005) Kladsko. Proměny Středoevropského Regionu: Historický Atlas [Kladsko Region. The Transformations of the Central European Region: A Historical Atlas]. Hradec Králové - Prague: Univerzita Hradec Králové, Historický ústav AV ČR. (In Czech)

Sharpley R (2000) Tourism and sustainable development: Exploring the theoretical divide. Journal of Sustainable Tourism, 8: 1-19.

https://doi.org/10.1080/09669580008667346

SHOCart (2002) Šumava: Turistická Mapa 1:100 ooo [Šumava: Tourist Map 1:100 000]. Vizovice: SHOCart spol. s r.o. (In Czech)

SHOCart (2008) Orlické Hory, Góry Stołowe: Turistická Mapa 1:50 ooo [Orlické Mountains, Table Mountains: Tourist Map 1:50 000]. Vizovice: SHOCart spol. s r.o. (In Czech)

Sroka P (2013) Turystyka w Polskich Sudetach w Latach 19451956 [Tourism in the Polish Sudeten Mountains in 19451956]. Wroclaw: Oficyna Wydawnicza "Atut". (In Polish)

Staffa M (1981) Zagospodarowanie terenów przygranicznych dla potrzeb turystyki górskiej w Sudetach [Development of border areas for the needs of mountain tourism in the Sudeten mountains]. Prace Karkonoskiego Towarzystwa Naukowego w Jeleniej Górze 21: 305-317. (In Polish)

Staffa M (1985) Z Zagadnień Zagospodarowania Turystycznego Gór Polskich [On Issues of Tourist Infrastructure in the Polish Mountains]. Warszawa - Kraków: Wydawnictwo PTTK Kraj, Redakcja Wydawnictw Górskich i Narciarskich. (In Polish)

Staffa M (1986) Zagospodarowanie turystyczne Sudetów po 1945 roku [Tourist infrastructure in the Sudeten mountains after 1945]. In: Turystyka Polska w Sudetach [Polish Tourism in the Sudeten Mountains]. Wroclaw: PTTK, pp 21-32. (In Polish)

Stasiak A (2006) Produkt turystyczny - szlak. Turystyka i Hotelarstwo 10: 9-40. (In Polish)

Stasiak A, Styperek J, Śledzińska J, Włodarczyk B, Zajadacz A (2014) Szlak turystyczny jako element przestrzeni geograficznej [Tourist trail as an element of geographical space]. In: Stasiak A, Śledzińska J, Włodarczyk B (eds.), Szlaki
Turystyczne: od Pomysłu do Realizacji [Tourist Trails: from Idea to Realization]. Warsaw - Łódź: Wydawnictwo PTTK "Kraj", pp 115-136. (In Polish)

Stasiak A, Śledzińska J, Włodarczyk B (2014) Funkcje szlaków turystycznych [Functions of tourist trails]. In: Stasiak A, Śledzińska J, Włodarczyk B (eds.), Szlaki Turystyczne - od Pomystu do Realizacji [Tourist Trails - from the Idea to the Implementation]. Warsaw: Wydawnictwo PTTK "Kraj", pp 173-182. (In Polish)

Styperek J (2001) Piesze szlaki turystyczne w polskich parkach narodowych [Hiking tourist trails in Polish national parks]. Turyzm 11(1): 25-37. (In Polish)

Styperek J (2002) Linearne Systemy Penetracji Rekreacyjnej [Linear Systems of Recreational Penetration]. Poznan: Wydawnictwo Naukowe Bogucki. (In Polish)

Těšitel J, Kušová D, Bartoš M (2003a) Role of tourism in development of rural marginal areas (region of Šumava Mts. in Czech Republic). European Rural Development Network Studies 1: 81-91.

Těšitel J, Kušová D, Bartoš M (2003b) Tourist's reasons for visiting mountain areas: a case study of the Sumava Mountains. Landscape Research 28(3): 317-322. https://doi.org/10.1080/01426390306520

Těšitel J, Kušová D (2010) Biosphere reserves - suggested model of the institution of commons (case study of the Šmava Biosphere Reserve). Journal of Landscape Ecology 3(2): 73-89. https://doi.org /10.2478/v10285-012-0028-x

Tyszkiewicz J (2006) Lata 1949-1955 [Years 1949-1955]. In: Wrzesiński W (ed.), Dolny Śląsk: Monografia Historyczna [Lower Silesia: Historical Monography]. Wroclaw: Wydawnictwo Uniwersytetu Wrocławskiego, pp 675-714. (In Polish)

Vaishar A, Dvořák P, Hubačíková V, Zapletalová J (2013) Contemporary development of peripheral parts of the CzechPolish borderland: case study of the Javorník area. Geographia Polonica 86(3): 237-253 http://doi.org/10.7163/GPol.2013.21

Vystoupil J, Šauer M (2012) Geography of tourism of the Czech Republic. In: Wyrzykowski J, Widawski K (eds.), Geography of Tourism of Central and Eastern Europe Countries. Wroclaw: Institute of Geography and Regional Development, University of Wroclaw. pp 103-139.

Więckowski M (2010) Tourism development in the borderlands of Poland. Geographia Polonica 83(2): 67-81. http://doi.org/10.7163/GPol.2010.2.5

Więckowski M (2013) Eco-frontier in the mountainous borderlands of Central Europe. The case of Polish border parks. Journal of Alpine Research 101(2).

https://doi.org /10.400o/rga.2107 